\title{
Working
}

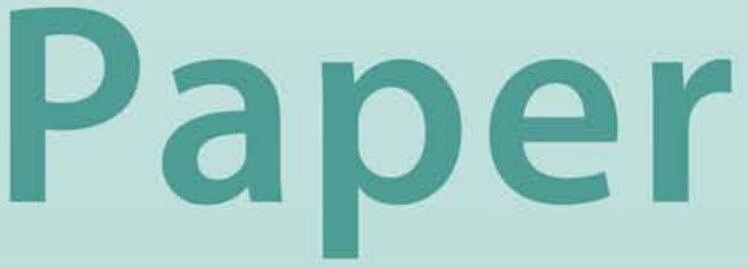




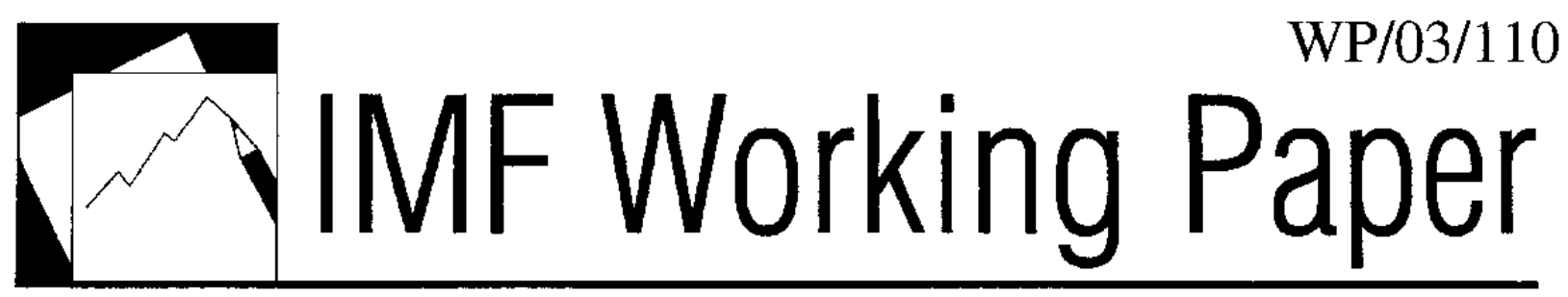

Measuring the Impact of Distortions in Agricultural Trade in Partial and General Equilibrium

Stephen Tokarick 


\title{
IMF Working Paper
}

\author{
Research Department
}

\section{Measuring the Impact of Distortions in Agricultural Trade in Partial and General Equilibrium}

\author{
Prepared by Stephen Tokarick ${ }^{1}$
}

Authorized for distribution by Peter Clark

May 2003

\begin{abstract}
The views expressed in this Working Paper are those of the author(s) and do not necessarily represent those of the IMF or IMF policy. Working Papers describe research in progress by the author(s) and are published to elicit comments and to further debate.
\end{abstract}

This paper provides quantitative estimates of the impact of removing agricultural support (both tariffs and subsidies) in partial- and general-equilibrium frameworks. The results show that agricultural support in industrial countries is highly distortionary and tariffs have a larger distortionary impact than subsidies. Removal of agricultural support would likely raise the international prices of food, resulting in an increase in the cost of food for many net-foodimporting countries, although the increase is generally small. The results also show that most of the benefits from removing agricultural support accrue to the countries that liberalize.

JEL Classification Numbers: Q17, F13

Keywords: Agricultural Trade, Tariffs, Subsidies, Models

Author's email address: Stokarick@imf.org

\footnotetext{
${ }^{\mathrm{I}}$ The author would like to thank Tam Bayoumi, Jim Cassing, Peter Clark, David Robinson and Clinton Shiells for comments on various drafts. Thanks to Youngzheng Yang for performing the GTAP simulations. Part of the analysis contained in this paper appeared in International Monetary Fund (2002).
} 


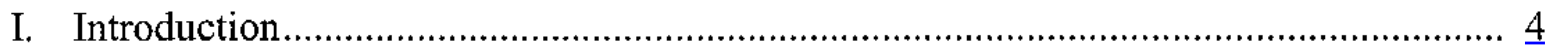

II. The Economics of Agricultural Support ................................................................ 5

III. Agricultural Support: Who Does What to Whom? ……............................................. 7

IV. Partial-Equilibrium Methodology for Assessing the Impact of Agricultural Support in Industrial Countries .............................................................12

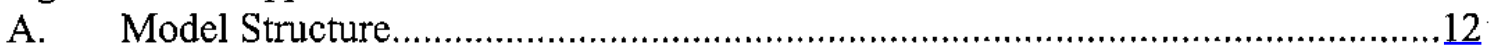

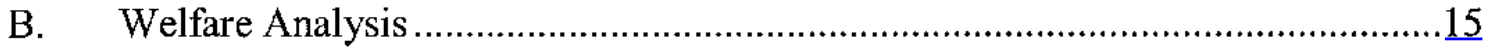

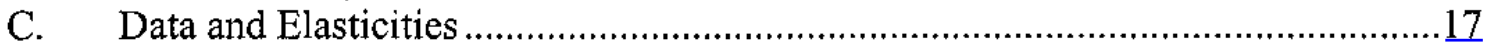

V. Impact of Removing Agricultural Support on OECD Countries:

Partial Equilibirum ....................................................................................................19

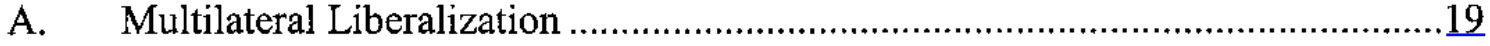

B. Impact of Multilateral Liberalization on Net-Food-Importing Countries ..............32

VI. Impact of Removing Agricultural Support: General-Equilibrium Results ......................36

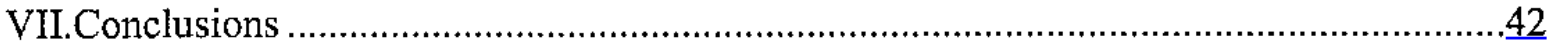

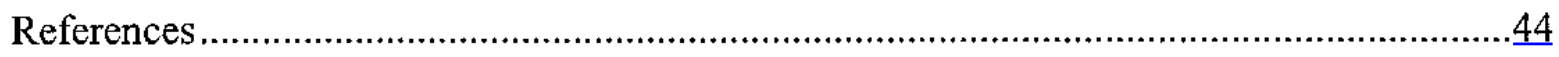

Text Tables:

1. Agriculture Support Measures for 2000 Used in the Partial-Equilibrium Model.............11

2. Effects on World Prices of Multilateral Agricultural Trade Liberalization.....................20

3. Welfare Effects of Multilateral Agricultural Trade Liberalization: Partial Equilibrium (Commodity: Beef) ...........................................................................................

4. Welfare Effects of Multilateral Agricultural Trade Liberalization: Partial Equilibrium (Commodity: Wheat)

5. Welfare Effects of Multilateral Agricultural Trade Liberalization: Partial Equilibrium (Commodity: Milk)

6. Welfare Effects of Multilateral Agricultural Trade Liberalization: Partial Equilibrium (Commodity: Rice)

7. Welfare Effects of Multilateral Agricultural Trade Liberalization: Partial Equilibrium (Commodity: Maize)

8. Welfare Effects of Multilateral Agricultural Trade Liberalization: Partial Equilibrium (Commodity: Cotton) ........................................................................................27

9. Welfare Effects of Multilateral Agricultural Trade Liberalization: Partial Equilibrium (Commodity: Sheepmeat)

10. Welfare Effects of Multilateral Agricultural Trade Liberalization: Partial Equilibrium (Commodity: Wool) 
11. Welfare Effects of Multilateral Agricultural Trade Liberalization: Partial Equilibrium (Commodity: Soybeans)

12. Welfare Effects of Multilateral Agricultural Trade Liberalization: Partial Equilibrium (Commodity: Refined Sugar)....

13. Increase in Import Costs as a Result of Removing Agricultural Support in

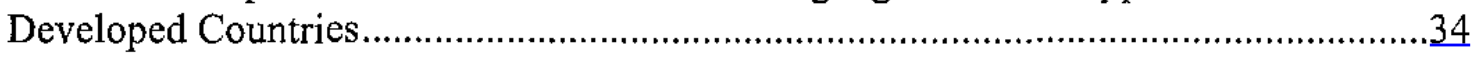

14. Welfare Effects of Agricultural Liberalization ..........................................................

15. Welfare Effects of Agricultural Liberalization by Developed Countries ........................39

Figures:

1. Welfare Effects of an Increase in the World Price in the Presence of an Import Subsidy.

2. Welfare Effects of Removing Production and Input Subsidies ....................................16

3. Welfare Effects of Removing an Import Tariff and an Input Subsidy ..........................18 


\section{INTRODUCTION}

To say that markets for agricultural commodities are highly distorted would be an understatement. Indeed, many countries - mainly the orgnization for Economic Cooperation and Development (OECD) countries with their high per capita income-provide support to their agricultural producers through a complex array of policy measures, such as tariffs that discriminate against agricultural imports, subsidies that enourage greater production and exports, and input subsidies that effectively lower the cost of production. These support policies are often cited as important obstacles to more rapid development of low-income countries, as well as a major reason farmers remain mired in poverty in developing countries. Both the International Monetary Fund and the World Bank have called on OECD countries to eliminate the support they provide to their agricultural sectors in order to reduce poverty and spur economic development. At the World Summit on Sustainable Development conference in Johannesburg in 2002, world leaders also called for a reduction (and eventual removal) of agricultural support in rich countries, especially on products of export interest to developing countries. Indeed, a broad-based, international consensus has emerged that agricultural support policies in OECD countries are detrimental to the interests of developing countries.

There is no question that agricultural support in OECD countries harms developing countries and the world as a whole. Thus, removal of support in OECD countries would raise real income in the world and developing countries as a group. But the inflamed political rhetoric has led many observers to lose sight of two important aspects of the economic impact of removing agricultural support, especially on developing countries. First, nearly all empirical studies demonstrate that the bulk of the costs of agricultural support fall on the country that imposes such policies and not on other countries. In other words, agricultural support policies hurt OECD countries relatively more than they hurt developing countries. As is well known, the costs of distortions depend on the size of the distortion, the relevant elasticities, and the share of the affected commodity in GDP (share of imports in the case of a tariff). ${ }^{2}$

The second aspect is that subsidies provided by many OECD countries actually benefit some poor, developing countries. This occurs because industrial countries generally apply subsidies to commodities that they export, which tends to stimulate production and thereby depress the world prices of these products. As a consequence, developing countries that are net importers of these commodities actually benefit from subsidies applied by industrial countries because they can import these goods at a lower price. The subsidies have opposing effects on different groups within the developing country, as producers would be hurt and consumers would benefit. On balance, in net-importing countries, the gain to consumers would outweigh the loss to producers. The results of a number of empirical

${ }^{2}$ For example, the impact of a tariff on welfare depends on the size of the tariff, the elasticity of demand for imports of the affected product, and the share of imports in GDP. See Johnson (1960) for a discussion. 
studies reveal that tariff barriers in OECD countries actually inflict more damage than subsidies on developing countries.

Agricultural subsidies in OECD countries do, however, hurt countries that are net exporters of subsidized products, as the subsidies reduce world prices and the export earnings of competing countries. Thus, the net impact of agricultural subsidies applied by OECD countries on developing countries depends on whether the country is a net importer or exporter of the product to which the subsidies apply. In the context of a multilateral initiative to remove agricultural support - as called for under the Doha Round of trade negotiationsrecognition should be taken of the differential impact of liberalization across countries. This was done in the context of the Uruguay Round, but needs to be kept in mind in future trade rounds as well.

The impact of agricultural support in OECD countries depends largely on the structure of trade across countries, the types of support, and the commodities to which they apply. As shown below, agricultural subisidies in OECD countries apply mostly to commodities that they export--temperate zone products such as grains (wheat and corn)tend to be net importers of these products. However, there are a few exceptions to this rule. Production of rice and cotton are subsidized in some OECD countries, and these products are important sources of export earnings for some poor countries. Products that constitute major sources of export earnings for developing countries, such as coffee, tea, and cocoa, are not subsidized in OECD countries largely because they are not produced there. As shown below, the major source of gains for developing countries would arise from removal of tariffs, rather than subsidies, in OECD countries. Therefore, to estimate the impact of agricultural support in OECD countries on developing countries, a detailed analysis, which takes into account the specific type of support and the net trade pattern by commodity and country, is required.

This paper has several objectives. First, the next section identifies the major factors that influence the size of the welfare impact of removing agricultural support in countries that liberalize, as well as those that do not. The third section provides a profile of the magnitude of agricultural support in OECD countries, the principal countries that intervene, and the commodities that are affected. The fourth section provides details on the partial-equilbrium model of trade used to quantify the effects of removing agricultural support, while the fifth section provides the welfare effects of liberalization in terms of the effects on consumers, producers, and the government. The section also identifies the extent to which some types of agricultural support are more distortionary than others. The calculated changes in world prices are then used to estimate the impact of removing agricultural support in OECD countries on net-food-importing developing countries. The sixth section of the paper assesses the impact of agricultural support in a the context of a global general equilibrium modelone that takes into account the complex linkages that exist across countries. The final sectiion concludes.

\section{The ECONOMICS OF AgRicultural Support}

This section lays out the main economic principles that are relevant for an evaluation of the welfare effects of removing agricultural support. The emphasis is on identifying the factors the influence the size of the changes in welfare on a country that undertakes 
liberalization, as well as on countries that are either competing importers or exporters and who may not liberalize.

For a net-importing country that consumes two goods--food (which is imported) and all other goods - the change in welfare is a price-weighted sum of the change in consumption of each good:

$$
d y=d D_{o}+p d D_{F}
$$

where dy is the change in real income, $d D_{O}$ is the change in consumption of goods other than food, $p$ is the domestic relative price of food (good $O$ is the numeraire), and $d D_{F}$ is the change in consumption of food. Using the budget constraint that expenditure equals income from production plus tariff revenue, the change in real income can be written as:

$$
d y=-M d p^{*}+\left(p-p^{*}\right) d M
$$

where $\mathrm{M}$ is the quantity of food imports, $\mathrm{dM}$ is the change in imports, and $\left(p-p_{*}^{*}\right)$ is the difference between the domestic relative price of food $(p)$ and the world price $\left(p^{*}\right)$ as a result of a support measure, such as a tariff.

Equation (2) demonstrates that the change in welfare due to a tariff can be decomposed into two parts: a distortionary effect $\left[\left(p-p^{*}\right) d M\right]$ and a terms-of-trade effect $\left[-M d p^{*}\right]^{3}$. In the case of a "small" country-one that cannot affect international prices - a tariff would only have a distortionatry effect, as $d p^{*}=0$. At an unchanged terms of trade, a tariff that reduces the quantity of imports $(d M<0)$ would lower real income. In this case, the degree of the welfare loss is directly related to the size of the tariff. In the case of a large country, the effects of a tariff are ambiguous: the tariff depresses the world price and confers a terms-of-trade gain $\left(d p^{*}<0\right)$, but it also introduces a distortionaty effect. ${ }^{4}$ For a netimporting country then, the net-welfare effect of a tariff depends on the size of the terms-oftrade gain, relative to the distortionary cost.

For net exporters, the change in real income can be expressed as:

$d y=E d p^{*}-\left(p-p^{*}\right) d E$

which is analogous to equation (2) for importers, where $E$ is the quantity of exports, $d E$ is the change in exports, $\left(p-p^{*}\right)$ is the difference between the domestic relative price and the world price $\left(p^{*}\right)$ of the subsidized export as a result of an export subsidy, and $d p^{*}$ is the change in the world price. As in the case of a tariff, the welfare effect of an export subsidy consists of a distortionary effect $\left[-\left(p-p^{*}\right) \mathrm{dE}\right]$ and a terms-of-trade effect $\left[E d p^{*}\right]$. Holding the terms of

\footnotetext{
${ }^{3}$ Martin (1996) obtains a similar decomposition using the balance of trade function.

${ }^{4}$ It is possible that a tariff could actually depress the world price to such an extent that the domestic price falls as well. This "paradox" known as Metzler's paradox, requires a "sufficiently inelastic" foreign offer curve. See Metzler (1949) for details.
} 
trade constant, an export subsidy reduces real income: the subsidy expands the volume of exports and raises $\mathrm{p}$ above $p^{*}$. In the large-country case, an export subsidy would depress the world price $\left(d p^{*}<0\right)$, which would also reduce welfare. Thus, in this case, the distortionary cost and the terms-of-trade effect reinforce each other, so welfare unambiguously declines.

Equations (2) and (3) are also useful in evaluating how liberalization by a group of countries (e.g. developed countries) affects countries that do not liberalize. In the first instance, the effects of removing agricultural support in one country on a competing exporter or importer come through changes in the terms of trade. Net-importing countries that do not have distortions in place would be hurt by an increase in the world price of the supported product, while competing exporters would benefit. These results follow simply from equations (2) and (3), assuming $p=p^{*}$.

When competing importers and exporters themselves have distortions in place (and $p \neq p^{*}$ ) the welfare effects of liberalization become more complicated, as noted by Anderson (1998) and Anderson and Tyers (1993). For example, in the case of net-importing countries, it is possible that an increase in world prices following liberalization could actually improve welfare, if these net-importing countries already have distortions in place. If imports are subsidized (perhaps to make them more affordable to the low-income segment of the population), then the quantity of imports consumed exceeds the optimum. An increase in the international price would therefore reduce imports and move consumption back toward the optimal amount. As shown in figure 1, the net welfare effect of an increase in the world price, in the presence of an import subsidy, depends on how subsidy expenditure changes (and a decline in the volume of imports). If subsidy expenditure declines sufficiently, an increase in the world price could generate a net welfare gain. In figure 1, the initial world price is $P W_{1}$ and the domestic price is $P D_{l}$, reflecting the fact that an import subsidy reduces the domestic price below the international price. For a given import subsidy, an increase in the international price to $P W_{2}$ would raise the domestic price to $P D_{2}$ and reduce the quantity of imports, because domestic production increases from $X_{1}$ to $X_{2}$ and domestic consumption declines from $D_{1}$ to $D_{2}$. The change in producer surplus is the sum of areas $\mathrm{A}+\mathrm{B}$, the change in consumer surplus is the areas $-(\mathrm{A}+\mathrm{B}+\mathrm{C}+\mathrm{D}+\mathrm{E})$, and the change in net government revenue is $(\mathrm{H}+\mathrm{O}+\mathrm{I}+\mathrm{P}+\mathrm{J}+\mathrm{B}+\mathrm{C}+\mathrm{D}+\mathrm{E}+\mathrm{F})$ less $(\mathrm{L}+\mathrm{M}+\mathrm{N}+\mathrm{O}+\mathrm{I}+\mathrm{P})$. Thus, the net welfare change is $(\mathrm{H}+\mathrm{J}+\mathrm{B}+\mathrm{F}-\mathrm{L}-\mathrm{M}-\mathrm{N})$, the sign of which is ambiguous. If a net-importing country has a tariff in place instead, an increase in the world price would lower welfare, because the price increase would exacerbate the effect of a tariff.

\section{Agricultural Support: Who Does What to Whom?}

Industrial countries use a complex array of policies to support their agricultural sectors. An important part of the support takes place through the market - that is, policies that create a wedge between the price received by an agricultural producer or the price paid by a consumer and the world price. This paper considers four types of agricultural support: import tariffs, export subsidies, production subsidies, and input subsidies. Following the OECD (2002), import tariffs and export subsidies are referred to as "market price support," 
Figure 1. Welfare Effects of an Increase in the World Price in the Presence of an Import Subsidy

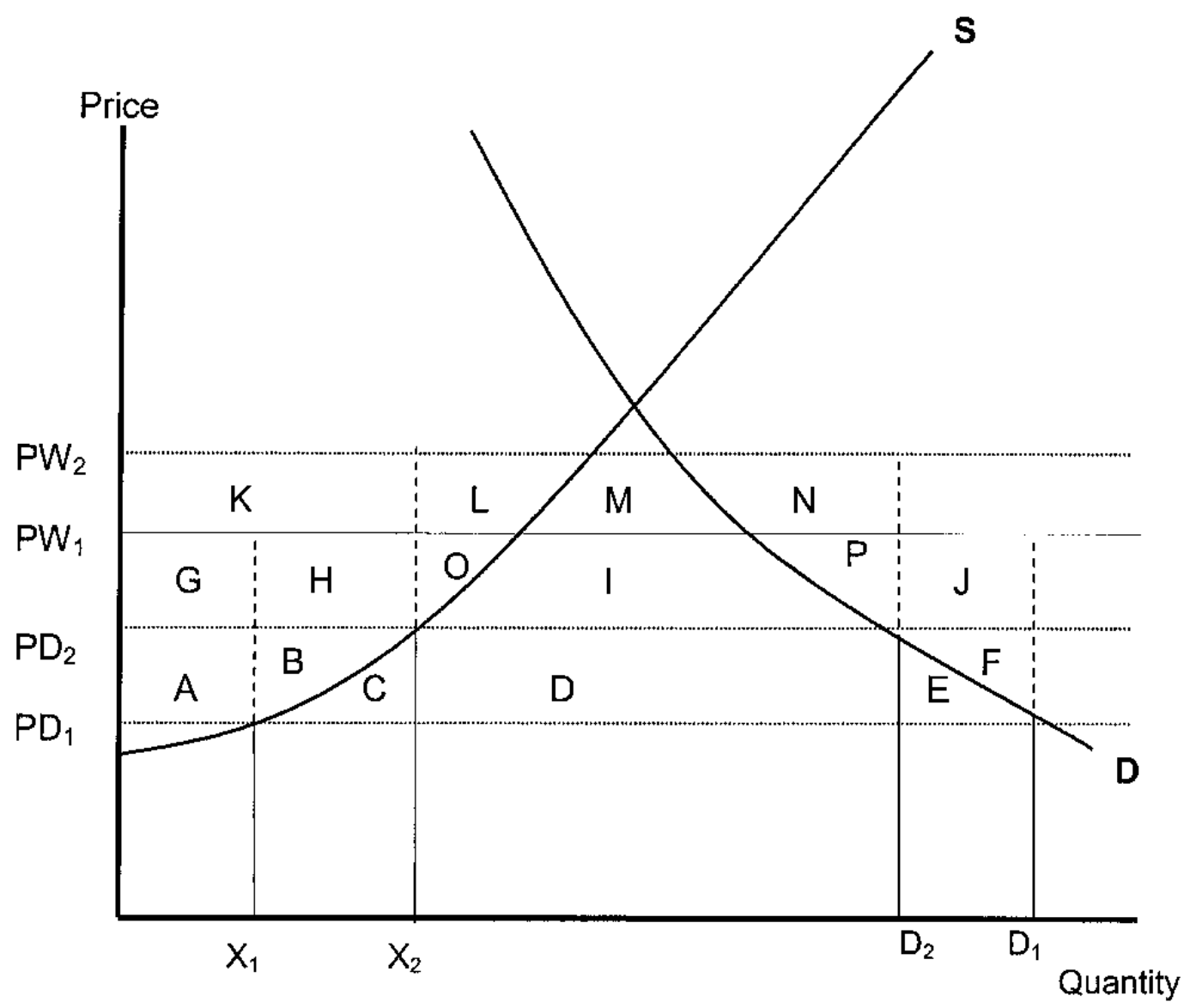

The net welfare effect equals the areas $\mathrm{H}+\mathrm{J}+\mathrm{B}+\mathrm{F}-\mathrm{L}-\mathrm{M}-\mathrm{N}$. 
as they affect both the price paid by consumers and the price received by producers for the supported commodity. The effects of this type of agricultural support are well known, but it is worthwhile to describe them briefly:

- Import tariffs raise the price paid by consumers and the price received by the producer above the world price. For countries that are "large" in world markets, a tariff will depress the international price. Empirical work by Cernat et al. (2002) and the International Monetary Fund (2002) suggest that tariffs have larger effects on welfare than other types of support, namely export and production subisides.

- For net exporters, export subsidies raise both consumer and producer prices in the exporting country above the world price. Export subsidies are used by only a few countries; the largest user is the European Union (EU). Total expenditure on export refunds by the EU amounted to EUR $\$ 3.4$ billion in 2001, down from EUR $\$ 5.6$ billion in 2000 .

- $\quad$ Production subsidies raise the price received by the producer of the supported commodity above the world price, but allows the consumer to face the world price. Production subsidies are applied to commodities that are both exported or imported across OECD countries. To maintain a price to producers that is above the world price, the government pays producers the difference between the world price and a support price.

- Input subsidies effectively lower the cost of producing a given level of output by lowering the price paid by agricultural producers for inputs. Their effects are similar to those of production subsidies.

Governments in OECD countries also provide support to agricultural producers through direct income payments that are not tied to prices or output. These payments are designed to supplement the income of agricultural producers and require government expenditure. It is difficult to assess, however, how this type of support affects markets, as it may not alter marginal production decisions. However, research suggests (OECD, 2001) that agricultural support policies that are directed toward supporting the income of farmers through transfers, rather than by altering prices, have a smaller distortionary impact in terms of their effects on trade and welfare.

According to the OECD (2002), there have been some important changes in the profile of agricultural support since the mid-1980s: 
- Total agricultural support provided by OECD countries amounted to US $\$ 331$ billion in 2001, equal to 1.3 percent of GDP. Despite this high level, support to producers has been on a downward trend since 1986-88. Across OECD countries, the aggregate producer support estimate (PSE) declined from 38 percent of farm receipts in $1986-88$ to 33 percent in $1999-2001 .^{5}$

- $\quad$ The major portion of the agricultural support still comes from measures that affect market prices - tariffs and export subsidies-but this component has declined over time as well. Approximately 82 percent of support to agricultural producers was due to maket price support in 1986-88, and this proportion declined to 70 percent in 1999-2001. There has been a shift away from "market price support" toward payments that are not directly linked to production.

- In 2001, support to agricultural producers, as measured by the PSE, was highest in Switzerland ( 69 percent), followed by Norway, Iceland, Japan and Korea. Support was lowest in New Zealand ( 1 percent). The commodities that receive the highest amounts of support include rice, sugar, and dairy products, especially milk.

- The overall level of agricultural support has declined only slightly in the EU in recent years, but there has been a significant decline in market price support. A growing portion of the support is now provided through direct income payments to farmers. On average in 2001, prices received by agricultural producers were 33 percent above world prices, which is also above the OECD average of 31 percent.

- $\quad$ Agricultural support in the United States, as measured by the PSE, declined in 1999-2001, compared to the period 1986-88. The overall level of support provided in the United States is lower than in the EU. On average in 2001 , prices received by agricultural producers were 15 percent above world prices.

Agricultural support policies that fit into one of four categories (tariffs, export subsidies, production subsidies, and input subsidies) are considered in this paper. Table 1 lists the degree of support, measured by comparing domestic and international prices for the commodities contained in the PSE database (OECD, 2002). Also, Table 1 lists the advalorem production subsidy rates, as well as a measure of input subsidies (per unit of output).

The price gaps for some commodities are extremely high, especially for milk, largely a result of stringent barriers to imports. Reflecting the high degree of market orientation (and hence the absence of border measures) in Australia and New Zealand, the prices paid by consumers in these countries are very close to world prices. Of the remaing countries, the price gap are lowest for the United States and highest for Japan and Korea, with significant price gaps for Switzerland and Norway.

\footnotetext{
${ }^{5}$ A PSE measures the total amount of support received by agricultural producers, expressed as a percentage of farm receipts. The PSE includes the support provided through tariffs, subsidies, and direct income payments. For a further details on the construction of the PSE, see OECD (2002).
} 
Table 1. Agriculture Support Measures For 2000 Used in the Partial-Equilibrium Model (Ad valorem rates, unless otherwise specified)

\begin{tabular}{|c|c|c|c|c|c|c|c|c|c|c|}
\hline & \multicolumn{7}{|c|}{ Beef and } & \multicolumn{3}{|c|}{ Refined } \\
\hline & Wheat & Maize & Rice & Veal & Milk & Cotton & Wool & Sheepmeat & Sugar & Soybeans \\
\hline \multicolumn{11}{|c|}{ Gaps Between Domestic } \\
\hline United States & na & na & na & 63.8 & 69.7 & 5.0 & 1.8 & 9.9 & 69.9 & na \\
\hline European Union & 9.0 & 20.9 & na & 19.9 & 69.9 & na & na & 25.2 & 229.3 & 5.4 \\
\hline Australia & na & na & 2.0 & na & na & na & na & na & na & na \\
\hline New Zealand & na & na & ла & na & na & na & na & na & na & na \\
\hline Switzerland & 143.6 & 92.5 & na & 194.4 & 173.3 & na & ла & 146.8 & 279.9 & 344.0 \\
\hline Iceland & na & na & na & 78.1 & 132.3 & na & na & na & na & na \\
\hline Norway & 145.2 & na & па & 75.1 & 132.8 & na & ла & 33.5 & na & na \\
\hline Canada & na & na & na & 51.1 & 112.6 & na & na & na & na & na \\
\hline Japan & 535.0 & na & 629.1 & 38.5 & 350.0 & па & na & na & 1040.2 & na \\
\hline Korea & na & na & 522.2 & 190.6 & 241.9 & na & na & na & na & 907.9 \\
\hline \multicolumn{11}{|c|}{ Production subsidy rates (s) } \\
\hline United States & 3.5 & 14.8 & 43.1 & na & 3.4 & 22.0 & ла & 3.5 & 3.0 & 27.9 \\
\hline European Union & na & na & 3.0 & na & 0.5 & na & na & na & 0.5 & 0.6 \\
\hline Switzerland & па & na & па & па & 13.0 & na & na & na & na & na \\
\hline Australia & па & na & па & па & na & na & na & na & na & 1.2 \\
\hline Iceland & na & na & na & na & 92.7 & na & na & 1.6 & na & na \\
\hline Norway & 28.2 & na & na & 22.3 & 33.4 & na & 177.4 & 22.2 & na & па \\
\hline Canada & 1.6 & 11.4 & па & 1.7 & 1.5 & na & na & na & na & 0.6 \\
\hline Japan & 98.4 & na & 5.5 & 2.6 & 3.9 & па & па & па & 6.3 & 83.9 \\
\hline \multicolumn{11}{|l|}{ Input subsidies $(\beta)$} \\
\hline \multicolumn{11}{|c|}{ (US\$ per unit of output) } \\
\hline United States & 0.05 & 0.05 & 0.05 & 0.03 & па & na & 0.02 & na & 0.05 & 0.05 \\
\hline European Union & 0.11 & 0.06 & 0.03 & 0.09 & na & 11a & 0.03 & na & 0.03 & 0.14 \\
\hline Australia & 0.03 & na & 0.03 & 0.03 & na & па & na & na & 0.1 & 0.03 \\
\hline New Zealand & na & па & nà & 0.01 & па & па & na & na & na & na \\
\hline Switzerland & 0.12 & 0.12 & ra & 0.05 & па & na & na & na & 0.08 & 0.14 \\
\hline Iceland & na & na & па & 0.06 & na & ла & 0.04 & na & na & na \\
\hline Norway & 0.11 & na & na & 0.39 & na & na & 1.67 & na & na & na \\
\hline Canada & 0.02 & 0.01 & na & 0.02 & na & па & $\mathrm{na}$ & na & na & 0.02 \\
\hline Japan & 0.13 & na & 0.05 & 0.03 & na & na & па & na & 0.36 & 0.35 \\
\hline Korea & na & na & 0.02 & 0.01 & na & па & na & na & na & 0.02 \\
\hline
\end{tabular}

Source: Organization For Economic Cooperation and Development (2001); and author's calculations 
Direct export promotion - through export subsidies - are used by only a few countries, notably the EU, and this type of support is more limited in terms of its coverage across commodities, compared to other support policies. Support to agricultural producers through production subsidies is more prevalent in the United States, especially as applied to grains, than in the EU. Producer support through input subsidies is common across all countries and commodities, but substantially smaller in magnitude than production subsidies and market-price support.

\section{Partial-Equilibrium Methodology For Assessing the ImPact of Agricultural SUPPORT IN INDUSTRIAL COUNTRIES}

This section presents the structure of a partial-equilibrium model of trade that is used to quantify the welfare effects of agricultural support policies noted above. The structure of the model is similar to other partial-equilibrium models used to assess the impact of agricultural support, such as the one used by the OECD (2001), Hoekman, $\mathrm{Ng}$, and Olarreaga 2002), and Vanzetti and Graham (2002). The model used by the OECD (2001) includes factor markets explicity, and thus, is able to assess the effects of input subsidies, while the models of Hoekman et al. and Vanzetti and Graham do not consider the impact of input subsidies. The model used in this paper evaluates the economic impact of input subsidies without modeling factor markets explicitly. For a given commodity, the model consists of supply and demand relationships in each country that applies some form of agricultural support. In addition, behavior in the rest of the world is captured through the specification of import demand and export supply functions. The market for each commodity must clear; therefore the world price adjusts to ensure this condition is satisfied. Commodities are treated as homogenous; therefore the law of one price is assumed to hold across countries. Since market clearing is imposed, the model could be interpreted as a framework that isolates the factors that influence adjustment in commodity markets in the long run, after agricultural support is fully eliminated.

\section{A. Model Structure}

This section presents a partial-equilibrium model that takes into account the main channels through which agricultural support affects welfare. For a given commodity that is subject to some form of agricultural support, domestic demand in country $k$ is a function of a demand price, $P D_{k}$ (which includes the support measures):

$$
D_{k}=D 0_{k}\left(P D_{k}\right)^{\eta_{k}}
$$

where $D O$ is a constant and $\eta$ is the price elasticity of demand. Similarly, supply in country $k$ is a function of the supply price, $P S_{k}$ :

$$
X_{k}=X 0_{k}\left(P S_{k}\right)^{\varepsilon_{k}}
$$

where $X O$ is a constant and $\varepsilon$ is the price elasticity of supply. Of course, both demand and supply depend on factors other than prices, e.g. income, but these are assumed to remain 
constant. Net exports of the supported product from country $k$ are simply the difference between production and domestic consumption:

$$
E_{k}=X_{k}-D_{k}
$$

Net exports from countries in the rest of the world are modelled as a upward sloping function of the world price:

$$
E X=E X 0(P W)^{\gamma}
$$

where $E X$ are net exports from the rest of the world, $E X O$ is a constant, $P W$ is the world price of the supported commodity, and $\gamma$ is the export supply elasticity. Similarly, demand for the supported product in the rest of the world (import demand by third countries) is a downward sloping function of the world price, $P W$ :

$$
M D=M D 0(P W)^{\delta}
$$

where $M D$ is import demand in the rest of the world, $M D O$ is a constant, and $\delta$ is the elasticity of demand for imports. The world price is determined where total imports $(M D)$ equal exports from the country applying the support $(E)$ plus exports from other countries $(E X)$ :

$$
E+E X(P W)=M D(P W)
$$

It remains to specify how agricultural support measures are treated in the model. In the case of a net exporting country applying support, the demand price in country k would be the same as the world price, unless the country in question applies an export subsidy. ${ }^{6}$ In this case:

$$
P D_{k}=P W(1+e)
$$

where $e$ is the ad-valorem export subsidy rate. If support in country $k$ takes the form of a production subsidy, an input subsidy, or both, then the demand price would equal the world price:

$$
P D_{k}=P W
$$

The supply price facing the producer in country $k\left(P S_{k}\right)$ depends on the precise type of agricultural support measure in place. For countries that apply an export subsidy only, the supply price is:

\footnotetext{
${ }^{6}$ Throughout the model, transport costs are ignored.
} 
$P S_{k}=P W(1+e)$

If support takes the form of a production subsidy, then the supply price is:

$P S_{k}=P W(1+s)$

where $\mathrm{s}$ is the ad-valorem rate of production subsidy. In this case, the demand price would be determined by equation $(7 \mathrm{~b})$.

OECD countries typically support their agricultural sectors through multiple measures (e.g. such as production and input subsidies), rather than just one. In the case where a country applies both production and input subsidies, the price facing the producer would equal the world price multiplied by the ad-valorem production subsidy rate, $\mathrm{s}$, plus a measure of the subsidy applied to inputs, $\beta$. To introduce input subsidies, define $\beta$ as total expenditure on input subsidies divided by the quantity of output, $X$ :

$$
\beta=\frac{b P_{i} I}{X}=b P_{i} a_{i}
$$

where $a_{i}$ is the amount of input $i$ used in the production of the final output, $b$ is the subsidy rate on inputs, and $I$ is the quantity of the intermediate input used in the production of $X$. Thus, the price to producers, inclusive of both the production and input subsidy is:

$$
P S_{k}=P W(1+s)+\beta
$$

The equations of the model are only slightly modified for the case where countries providing agricultural support are net importers instead of exporters. When net importers apply support through a tariff, the demand price $P D$, will differ from the world price, $P W$ by the relevant tariff rate $t$ :

$$
P D_{k}=P W(1+t)
$$

and the supply price, $P S_{k}$ is given by:

$$
P S_{k}=P W(1+t)
$$

Also, the demand for imports in country $k, M D_{k}$, would be determined by the excess of domestic demand over domestic production:

$M D_{k}=D_{k}-X_{k}$

Thus, for the case of net importers, equations (3), (7a), and (10) are replaced by equations (11), (12), (13). The equations specified above characterizes a simultaneous system that determine all of the endogenous variables, PD, PS, PW, D, X, E, EX, and MD. 


\section{B. Welfare Analysis}

This section examines the welfare effects of removing two common types of agricultural support in the context of two cases. In the first, the welfare effects of removing both a production and an input subsidy are examined for the case of a net-exporting country. The second case details the welfare effects of removing an import tariff and an input subsidy for a net-importing country. Other combinations of support measures are possible, but these are perhaps the most common cases. In analyzing the effects of any change in trade policy, the net change in welfare is comprised of a change in producer surplus, consumer surplus, and net government revenue, as shown in Corden (1957). These principles are applied to an analysis of the net welfare effects of removing agricultural support.

\section{Case of a Production Subsidy and Input Subsidy Applied to an Exportable Commodity}

Figure 2 depicts the effects of agricultural support applied through both a production and an input subsidy. The example assumes that the producer receiving the support is a net exporter. As shown, support reduces welfare in the affected market because it distorts producer behavior and requires budgetary expenditure, which must be financed either from borrowing or taxation, which are generally distortionary. It is assumed that lump-sum taxation is not available.

Initially, the world price is $\mathrm{PW}_{1}$, which is determined by the intersection of world demand and supply. As both the production and input subsidy do not create a wedge between the world price and the price paid by consumers, $\mathrm{PD}_{1}=\mathrm{PW}_{1}$. The price facing producers, $\mathrm{PS}_{1}$, (equal to $\mathrm{PW}_{1}(1+\mathrm{s})+\beta$ ) differs from the world price as a consequence of the production subsidy, $s$, and the input subsidy $\beta$. At price $\mathrm{PS}_{1}$, output is $\mathrm{X}_{1}$. So at intital prices, the difference between production and consumption $\left(\mathrm{X}_{1}-\mathrm{D}_{1}\right)$ equals the quantity of exports (figure 2).

Removal of both the output and input subsidy would shift the supply curve from $\mathrm{S}_{1}$ to $\mathrm{S}_{2}$. The lower level of output would raise the world price to $\mathrm{PW}_{2}$, if the country in question is large enough in world markets to affect international prices. Once all distortions are eliminated, the new producer price, $\mathrm{PS}_{2}$ must equal the consumer price $\mathrm{PD}_{2}$, and both of these prices must equal the new world price $\mathrm{PW}_{2}$. At these new prices, the quantity consumed declines to $\mathrm{D}_{2}$ and production falls to $\mathrm{X}_{2}$.

Removal of both types of agricultural support reduces consumer surplus by the sum of areas $\mathrm{G}$ and $\mathrm{H}(-(\mathrm{G}+\mathrm{H}))$, as consumers pay a higher price. Producer surplus declines by the sum of areas $A, C$, and $D(-(A+C+D)$ : the change in producer surplus associated with the undistorted supply curve $\left(\mathrm{S}_{2}\right)$ between the orginal supply price $P S_{1}$ and the new equilibrium price, $\mathrm{PS}_{2}$ (figure 1). The change in the government budget is $(\mathrm{A}+\mathrm{B}+\mathrm{C}+\mathrm{D}+\mathrm{E}+\mathrm{F}+\mathrm{G}+\mathrm{H}+\mathrm{I}+\mathrm{J}+\mathrm{K}+\mathrm{L})$ (figure 1), which is positive, as expenditure is reduced. Therefore, the net welfare gain from liberalization is $(B+E+F+I+J+K+L)$. The area $(B+E+F)$ measures the efficiency gain on the supply side, while $(\mathrm{I}+\mathrm{J}+\mathrm{K}+\mathrm{L})$ is the terms-of-trade gain, measured relative to the initial quantity of exports. 
Figure 2. Welfare Effects of Removing Production and Input Subsidies

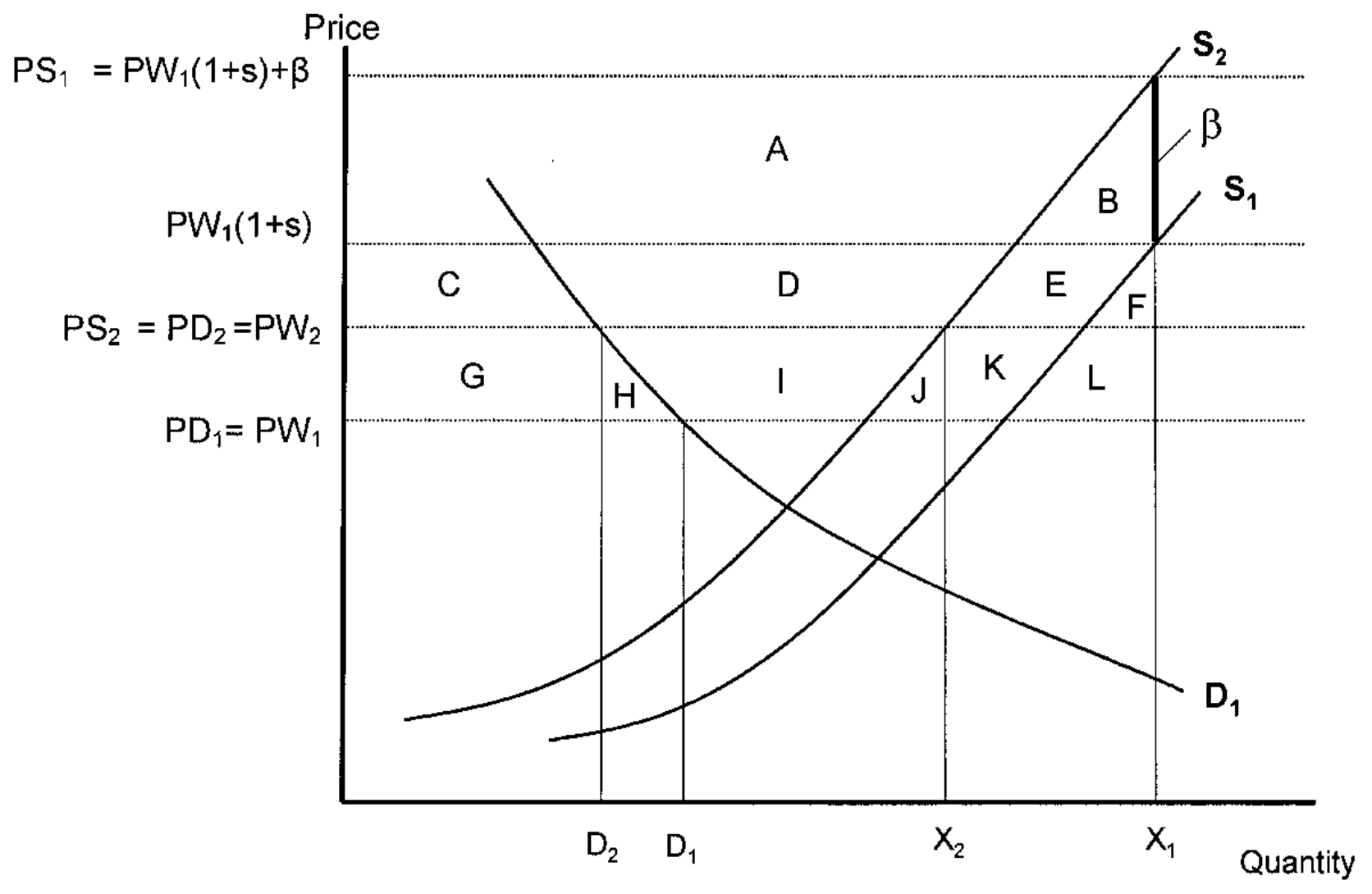

The net welfare gain from removing both types of subsidies is the sum of areas $\mathrm{B}+\mathrm{E}+\mathrm{F}+\mathrm{I}+\mathrm{J}+\mathrm{K}+\mathrm{L}$, where $(\mathrm{B}+\mathrm{E}+\mathrm{F})$ represents the gain in production efficiency and $(\mathrm{I}+\mathrm{J}+\mathrm{K}+\mathrm{L})$ represents the terms-of-trade improvement. 


\section{Case of a Import Tariff and Input Subsidy Applied by a Net Importer}

Figure 3 demonstrates the effects of removing a tariff on imports and an input subsidy for the case where the country is a net importer. Initially, the price facing producers is $\mathrm{PS}_{1}$, which differs from the world price $\mathrm{PW}_{1}$ as a consequence of both the tariff and the input subsidy. The price facing consumers, $\mathrm{PD}_{1}$, differs from the world price by the tariff. At these initial prices, production is at $X_{1}$ and consumption is at $D_{1}$, so the quantity of imports equals $\left(\mathrm{D}_{1}-\mathrm{X}_{1}\right)$.

Removal of both the import tariff and the input subsidy will result in a smaller quantity of output (a decline from $\mathrm{X}_{1}$ to $\mathrm{X}_{2}$ ), as the price facing the producer declines to $\mathrm{PS}_{2}$. Also, tariff removal results in a lower price paid by consumers, $\mathrm{P}_{2}$ and a corresponding increase in consumption to $\mathrm{D}_{2}$. If the country in question is large in world markets, the world price would rise to $\mathrm{PW}_{2}$. After removal of all support, both the producer and consumer prices fall, and they equal the world price, as there are no distortions in place. Following liberalization, the quantity of imports rises from $\left(D_{1}-X_{1}\right)$ to $\left(D_{2}-X_{2}\right)$.

Overall, the net welfare effect of liberalization is ambiguous. The loss in producer surplus is equal to the sum of areas $(A+D)$, while the gain in consumer surplus equals the sume of areas $\mathrm{D}+\mathrm{E}+\mathrm{F}+\mathrm{G}$. The effect on net government revenue is ambiguous, because both tariff revenue and subsidy expenditure decline. The government gains net revenue, equal to areas $(\mathrm{A}+\mathrm{B})$ (the decline in subsidy expenditure), but loses tariff revenue, equal to areas $(\mathrm{F}+\mathrm{H})$. Therefore, as shown in Figure 2, the net welfare gain from liberalization is the sum of areas $B, E$, and $G$ less area $H$. The areas $(B+E)$ measures the increase in efficiency on the supply side and area $\mathrm{G}$ is the increase in consumer efficiency. These gains are balanced against the terms-of-trade loss, (area $\mathrm{H}$ ), so the net welfare effect of liberalization is ambiguous. If there is a net welfare gain, it would likely be larger than the gain from just removing the tariff, because the input subsidy intensifies the tariff distortion. With a tariff only in place, area E would measure the efficiency gain on the supply size, which is obviously smaller than $(\mathrm{B}+\mathrm{E})$.

\section{Data and Elasticities}

Agricultural support is represented by four types of measures in the model: tariffs, export subisidies, production subsidies, and input subsidies. Data on agricultural support for all commodities, except cotton, were taken from the producer/consumer support estimate (PSE/CSE) database maintained by the OECD (2001). Support measures for cotton were constructed from budget data maintained by the U.S. Department of Agriculture. The gaps between consumer and world prices in the PSE/CSE database are used to represent marketprice support- - tariffs and export subsidies. For the net-importing countries, the percentage price gaps are used to represent tariffs $(t)$, while for net-exporting countries, the price gaps are used to represent export subsidies (e). The production subsidy rates, (s), are obtained by taking dividing "payments based on output" as reported in the PSE/CSE database by the value of output. 
Figure 3. Welfare Effects of Removing an Import Tariff and an Input Subsidy

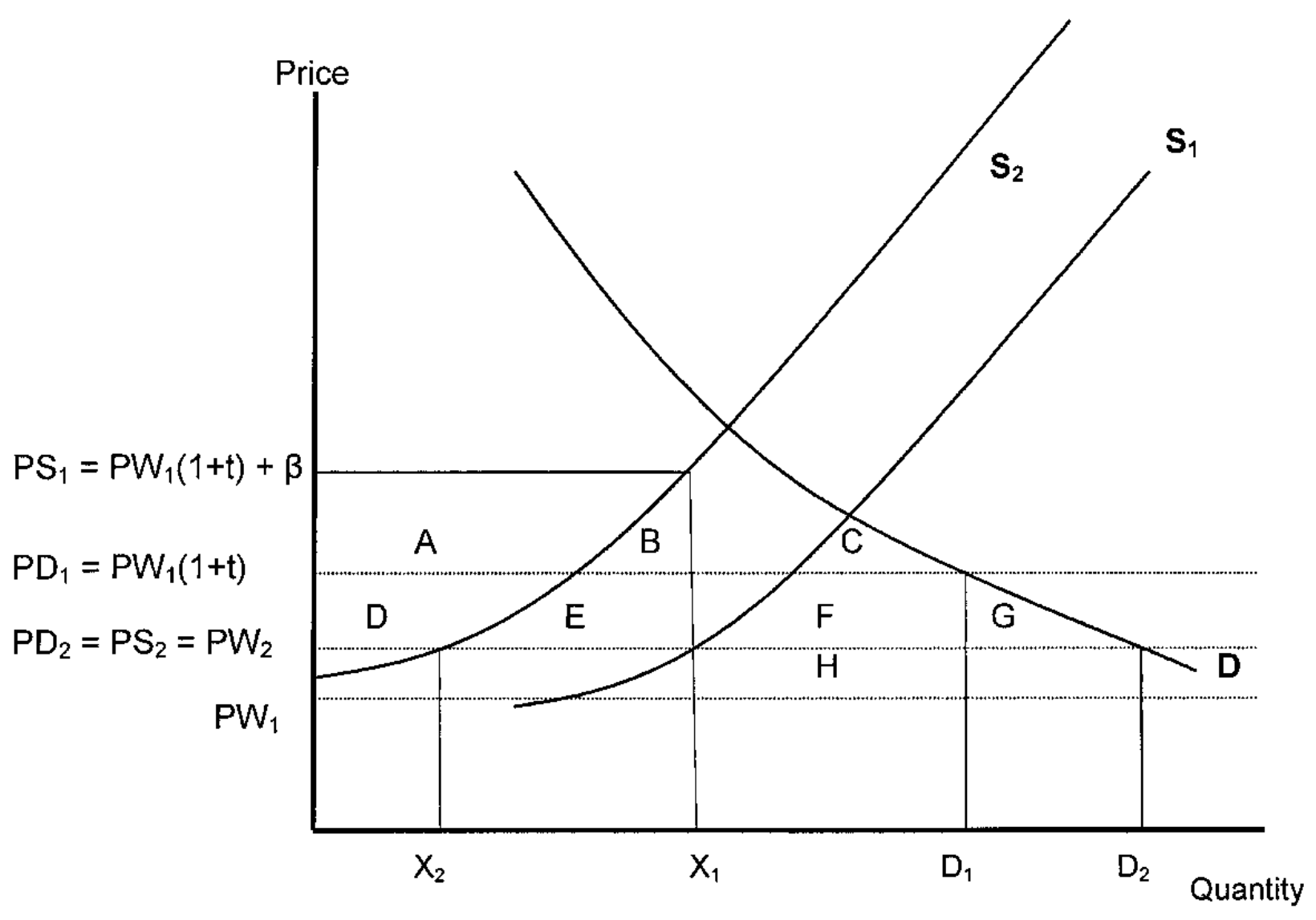

The net welfare effect is the sum of the areas $B+E+G-H$, where $(B+E)$ is the gain in production efficiency, $\mathrm{G}$ is the gain in consumption efficiency and $\mathrm{H}$ is the terms-of-trade loss. 
The data used in this paper for production subsidies differ from the one used by Hoekman et al. (2002), who used the information on aggregate measures of support (AMS) from country notifications to the World Trade Organization (WTO). The AMS data have a number of limitations, perhaps most importantly, the fact that they use a fixed base period1986 to 1988 - to measure price support. As is well known, the welfare costs of agricultural support depend on the size of the "wedge" between current domestic and world prices, not the size of the wedge compared to the base period 1986-88. Therefore, AMS data are not used in this paper. Finally, values for $\beta$, the parameter that represents input subsidies, is obtained by dividing "payments based on input usage" in the PSE/CSE database, by the quantity of output. Data on production are are also taken from the PSE/CSE database. Data on trade flows, (exports and imports) on a country basis, are taken from the Food and Agricultural Organization (FAO). The benchmark year for all data is 2000 .

The partial-equilibrium model requires four elasticity parameters for each commodity: the own-price elasticity of demand, the own-price elasticity of supply, the import demand elasticity in the rest of the world, and the export supply elasticity in the rest of the world. Values for both the domestic demand and supply elasticities by commodity and country were taken from Gardiner et al. (1989). Values for these elasticities were also crosschecked with those contained in OECD (2001) to insure broad consistency. Best-guess estimates were used for both the import demand and export supply elasticities. In most cases, the value used for the import demand elasticity was -0.75 , and the values used for the export supply elasticity ranged from 1.5 to 10 , depending on the product, so that the behavior of the rest of the world would correspond roughly to a "small" country in theory.

The model is used to perform four simulations: removal of market-price support, removal of production subsidies, removal of input subsidies, and removal of all forms of support. Each of these four simulations are performed on a multilateral basis, that is, all countries are assumed to liberalize at the same time.

\section{ImPaCt OF REMOVIng Agricultural Support on OECD COUNTRIES: PARTIAL EquiLibrium}

\section{A. Multilateral Liberalization}

This section presents the results from using the partial-equilibrium model described in section three to estimate the welfare effects of multilateral agricultural trade liberalization in OECD countries. The results are presented for ten commodities: wheat, maize, rice, milk, cotton, sheepmeat, soybeans, refined sugar, wool, and beef and veal. The welfare effects of eliminating agricultural support are broken down into three parts: the change in producer surplus, change in consumer surplus, and change in government net revenue. As shown previously, terms-of-trade effects are part of the change in net government revenue.

In general, all of the liberalization scenarios performed result in an increase in the international price of the supported commodity (Table 2). This occurs because removing agricultural support in net-exporting countries reduces output and exports of the supported commodity. Net-exporting countries that liberalize gain from removing agricultural support for two reasons: a terms-of-trade improvement and efficiency gains from better resource 
Table 2. Effects on World Prices of Multilateral Agricultural Trade Liberalization (Pcrentage changes)

\begin{tabular}{|c|c|c|c|c|}
\hline & $\begin{array}{c}\text { Removal } \\
\text { of Market } \\
\text { Price Support }\end{array}$ & $\begin{array}{c}\text { Removal of } \\
\text { Produclion } \\
\text { Subsidies }\end{array}$ & $\begin{array}{l}\text { Removal of } \\
\text { Inpul } \\
\text { Subsidies }\end{array}$ & $\begin{array}{c}\text { Removal of } \\
\text { All } \\
\text { Support }\end{array}$ \\
\hline Beef and veal & 1.7 & 0.0 & 0.2 & 1.7 \\
\hline Wheat & 2.7 & 0.2 & 1.2 & 3.9 \\
\hline Milk & 22.9 & 1.0 & 1.0 & 23.6 \\
\hline Rice & 0.9 & 1.2 & 0.2 & 2.3 \\
\hline Maize & 1.3 & 1.3 & 0.6 & 3.1 \\
\hline Cotton & 0.8 & 2.0 & na & 2.8 \\
\hline Refined sugar & 7.8 & 0.1 & 0.2 & 8.0 \\
\hline Wool & 0.0 & 0.0 & 0.1 & 0.1 \\
\hline Sheepmeat & 19.4 & 0.2 & 2.2 & 22.2 \\
\hline Soybeans & 1.0 & 1.8 & 0.5 & 3.2 \\
\hline
\end{tabular}

Source: Author's calculations. 
allocation. Net-importing countries that liberalize suffer a terms-of-trade loss, but enjoy and efficiency gain. In nearly all cases, the efficiency gains exceed the terms-of-trade losses.

Tables 3 through 12 present the welfare effects on the countries that remove their agricultural support to the ten commodities mentioned above. As shown, when all countries remove all forms of support, that is, if all price gaps and subsidies were to be eliminated simulataneously, all countries tend to gain, with a few exceptions. In the case of maize, when all countries remove support simulataneously, Canada suffers a small welfare loss (US\$4.6 million). This occurs because Canada is a net importer of maize, and the terms-oftrade loss outweighs the efficiency gains from removing its own support. Two points should be made about this result. First, Canada would gain (about US\$1 million) if it were to remove its support on maize while all other countries maintained their support. Second, even though Canada would suffer a welfare loss if all countries liberalize, it would lose even more if it did not liberalize with the rest of the world. This is because if it did not liberalize, it would only suffer a terms-of-trade loss (US $\$ 5 \frac{1}{2}$ million), which would be greater than the loss it would incur from liberalizing (US\$4.6 million). By liberalizing, it reaps effciency gains, as it would suffer a terms-of-trade loss in either case. Thus, it pays Canada to join with other countries in removing its support on maize.

In the case of sheepmeat, when all countries liberalize, two countries-the United States and the European Union--lose. The European Union loses because the terms-of-trade losses far outweigh the efficiency gains. The European Union has market power in sheepmeat: it is the largest producer and imports half of total world trade. The United States would suffer a welfare loss because the terms-of-trade deterioration outweighs the efficiency gains from removing its relatively low level of support. In soybeans, the European Union loses when all countries liberalize: the terms-of-trade deterioration exceed the efficiency gains. Like the case of maize, it would be in the interest of the European Union to liberalize, as it would suffer a terms-of-trade loss if it did nothing.

The welfare gains are largest when support on milk and milk products is eliminated, reflecting the large price gaps that exist across countries. Simultaneous removal of all support on milk would raise welfare in the United States by over US\$3 billion, and by over US $\$ 7$ billion in the EU. As shown, consumers bear large costs of supporting the milk sector. The net-exporters with a comparative advantage in milk products-Australia and New Zealand - also gain because of the substantial terms-of-trade improvement. In beef and veal, where there is also significant support in place, the welfare gains exceed US\$6 billion for the United States, US $\$ 0.8$ billion for Switzerland ( .34 percent of GDP), and US $\$ 0.7$ billion of Korea (.16 percent of GDP). As with milk, consumers would reap large gains from liberalization, while producers would lose. In these simulations, removal of all support on beef and veal causes Canada to switch from a net-exporter to a net-importer, and exports from the EU fall by more than half.

As shown, the welfare results of liberalization depends importantly on the type of agricultural support measure that is eliminated. For example, the simulations support the conclusion that production subsidies are harmful because they distort trade and lower world prices. However, some countries may lose as a result of just removing production subsidies, 
Table 3. Welfare Effects of Multilateral Agricultural 'Trade Liberalization: Partial Equilibrium (Commodity; Beef) (I m millions of 2000 U.S. Dollars, unless odterwise specified)

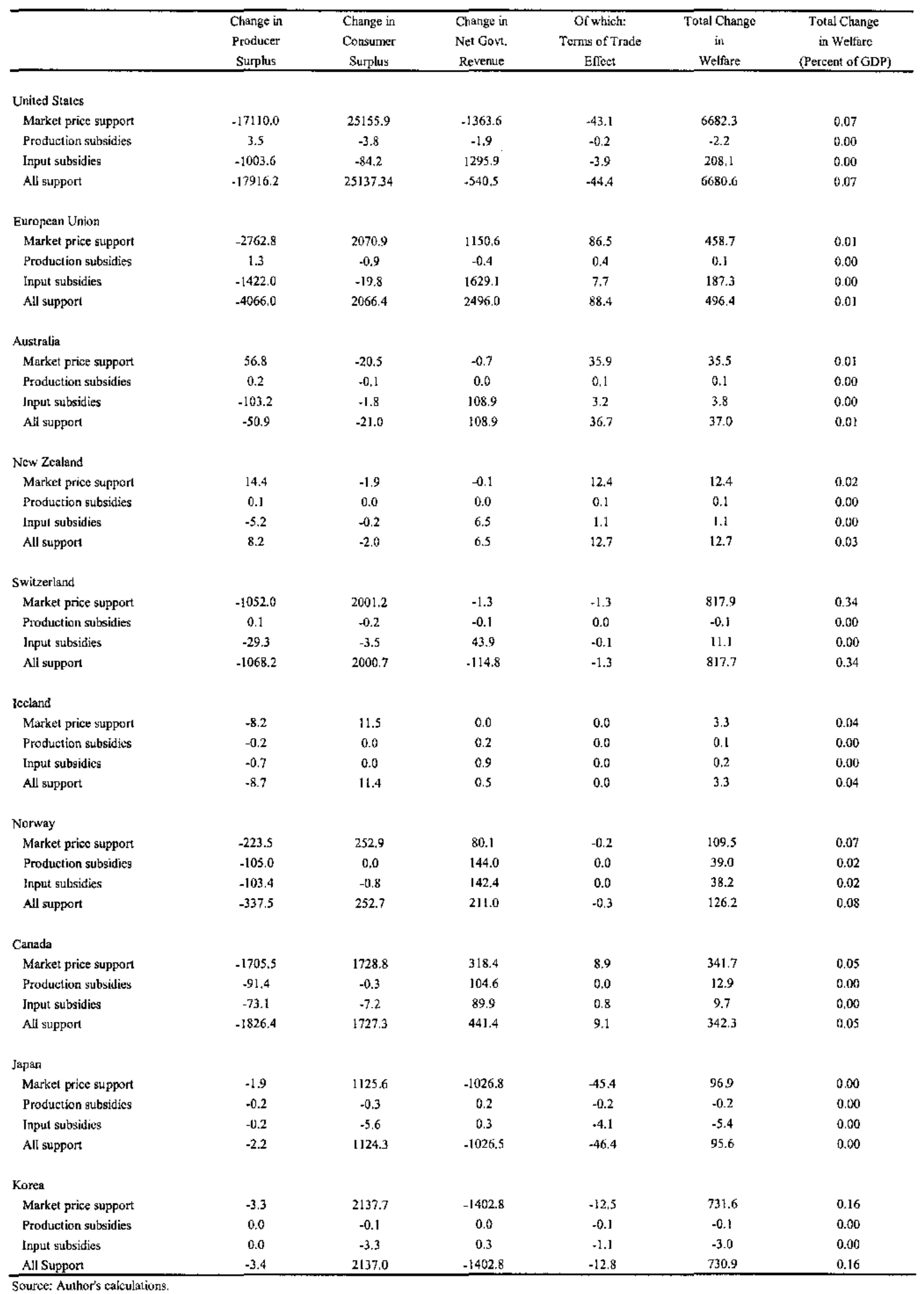


Table 4. Welfare Effects of Multilateral Agricultural Trade Liberalization: Partial Equilibrium (Commodity: Wheat) (In millions of 2000 U.S. Dollars, unless otherwisc spocified)

\begin{tabular}{|c|c|c|c|c|c|c|}
\hline & $\begin{array}{c}\text { Change in } \\
\text { Producer } \\
\text { Surplus } \\
\end{array}$ & $\begin{array}{l}\text { Change in } \\
\text { Consumex } \\
\text { Surplus }\end{array}$ & $\begin{array}{l}\text { Change in } \\
\text { Net Govt. } \\
\text { Revenue }\end{array}$ & $\begin{array}{c}\text { Of which: } \\
\text { Tems of Trade } \\
\text { Effect }\end{array}$ & $\begin{array}{c}\text { Total Change } \\
\text { in } \\
\text { Welfare } \\
\end{array}$ & $\begin{array}{c}\text { Total Change } \\
\text { in Welfare } \\
\text { (Percent of GDP) }\end{array}$ \\
\hline \multicolumn{7}{|l|}{ United States } \\
\hline Market price support & 165.9 & -62.9 & -15.9 & 95.7 & 87.2 & 0.00 \\
\hline Production subsidies & -187.5 & -5.2 & 210.0 & 7.9 & 17.2 & 0.00 \\
\hline Input subsidics & -220.7 & -26.9 & 297.4 & 40.8 & 49.8 & 0.00 \\
\hline All support & $-264,0$ & -90.3 & 496.8 & 137.6 & 142.5 & 0.00 \\
\hline \multicolumn{7}{|l|}{ European Union } \\
\hline Market price support & -710.5 & 444.9 & 444.4 & 121.2 & 178.8 & 0.00 \\
\hline Production subsidies & 24.4 & -17.2 & 0.0 & 10 & 7.1 & 0.00 \\
\hline Input subsidies & -1060.7 & -88.8 & 1282.8 & 51.7 & 133.3 & 0.00 \\
\hline All support & -1744.1 & 360.2 & 1639.6 & 174.4 & 255.7 & 0.00 \\
\hline \multicolumn{7}{|l|}{ Australia } \\
\hline Market price support & 69.5 & -7.4 & -1.7 & 61.4 & 62.1 & 0.02 \\
\hline Production subsidies & 5.7 & -0.6 & -0.1 & 5.1 & 4.9 & 0.00 \\
\hline Input subsidies & -57.3 & -3.2 & 87.2 & 26.2 & 26.7 & 0.01 \\
\hline All support & 11.9 & -10.6 & 87.2 & 88.4 & 88.4 & 0.02 \\
\hline \multicolumn{7}{|l|}{ New Zealand } \\
\hline Market price support & 1.0 & -1.0 & 0.0 & 0.0 & 0.0 & 0.00 \\
\hline Production subsidics & 0.1 & -0.1 & 0.0 & 0.0 & 0.0 & 0.00 \\
\hline Input subsidies & 0.4 & -0.4 & 0.0 & 0.0 & 0.0 & 0.00 \\
\hline All support & 1.5 & -1.4 & 0.0 & 0.0 & 0.0 & 0.00 \\
\hline \multicolumn{7}{|l|}{ Switzerland } \\
\hline Market price support & -277.5 & 445.6 & .58 .6 & -1.3 & 109.5 & 0.05 \\
\hline Production subsidies & 1.3 & -1.6 & 69.5 & -0.1 & -0.8 & 0.00 \\
\hline Input subsidies & -22.0 & -8.3 & 37.2 & -0.6 & 7.0 & 0.00 \\
\hline All support & -292.6 & 441.4 & -41.3 & -1.9 & 307.5 & 0.04 \\
\hline \multicolumn{7}{|l|}{ Norway } \\
\hline Market price support & -111.2 & 156.7 & 5.3 & -0.7 & 50.7 & 0.03 \\
\hline Production subsidies & -48.4 & -0.6 & 69.5 & -0.1 & 20.5 & 0.01 \\
\hline Input subsidies & -5.8 & -2.9 & 10.6 & -0.3 & 1.9 & 0.00 \\
\hline All support & -127.0 & 155.2 & 23.2 & -1.0 & 51.4 & 0.03 \\
\hline \multicolumn{7}{|l|}{ Canada } \\
\hline Market price support & 63.8 & -6.6 & -2.8 & 55.5 & 54.4 & 0.01 \\
\hline Production subsidies & -32.3 & -0.5 & 38.1 & 4.6 & 5.3 & 0.00 \\
\hline Input subsidies & -25.7 & -2.8 & 52.6 & 23.7 & 24.1 & 0.00 \\
\hline All support & -1.0 & -9.5 & 90.3 & 79.8 & 79.8 & 0.01 \\
\hline \multicolumn{7}{|l|}{ Japan } \\
\hline Market price support & -7.4 & 7828.7 & -5506.1 & -28.0 & 2315.2 & 0.05 \\
\hline Production subsidies & -5.1 & -14.7 & 13.5 & -2.3 & -6.2 & 0.00 \\
\hline Input subsidies & 0.0 & -75.6 & 31.8 & -11.9 & -43.8 & 0.00 \\
\hline All support & -7.8 & 7798.3 & -5505.7 & -40.2 & 2284.8 & 0.05 \\
\hline
\end{tabular}

Source: Author's calculations. 
Tabie 5. Welfare Effects of Multilateral Agricultural Trade Liberalization: Partial Equilibrium (Commodity: Milk) (in millions of 2000 U.S. Dollars, unless otherwise specified)

\begin{tabular}{|c|c|c|c|c|c|c|}
\hline & $\begin{array}{l}\text { Change in } \\
\text { Producer } \\
\text { Surplus } \\
\end{array}$ & $\begin{array}{c}\text { Change in } \\
\text { Consumer } \\
\text { Surplus } \\
\end{array}$ & $\begin{array}{l}\text { Change in } \\
\text { Net Govt. } \\
\text { Revenuc } \\
\end{array}$ & $\begin{array}{c}\text { Of which: } \\
\text { Terms of Trade } \\
\text { Effect } \\
\end{array}$ & $\begin{array}{l}\text { Total Change } \\
\text { in } \\
\text { Welfarc } \\
\end{array}$ & $\begin{array}{c}\text { Total Change } \\
\text { in Welfare } \\
\text { (Percent of GDP) }\end{array}$ \\
\hline \multicolumn{7}{|l|}{ United States } \\
\hline Market price support & -8288.1 & $\$ 1584.6$ & -59.1 & -309.3 & 3237.4 & 0.03 \\
\hline Production subsidies & -855.7 & -355.1 & 1571.1 & -12.9 & 360.3 & 0.00 \\
\hline Input subsidies & $-407,0$ & -355.5 & 8.7 & .12 .9 & 109.4 & 0.00 \\
\hline All support & -9230.5 & 11378.9 & 1018.7 & -319.2 & 3167.0 & 0.03 \\
\hline \multicolumn{7}{|l|}{ European Union } \\
\hline Market price support & -14159.1 & 8181.8 & 13221.7 & 4179.1 & 7244.4 & 0.10 \\
\hline Production subsidies & 243.5 & -264.4 & 50.0 & 174.0 & 29.1 & 0.00 \\
\hline Input subsidies & $-590,0$ & -264.7 & 1229,6 & 174.2 & 374.8 & 0.01 \\
\hline All suppor & -14976.3 & 8045.2 & 14235.2 & 4313.2 & 7304.2 & 0.10 \\
\hline \multicolumn{7}{|l|}{ Australia } \\
\hline Market price support & 430.5 & $-7,2$ & -14.8 & 369.3 & 408.6 & 0.11 \\
\hline Production subsidies & 15.8 & -0.3 & -0.6 & 15.4 & 14.9 & 0.00 \\
\hline Inpul subsidius & .35 .2 & -0.3 & 51.3 & 15.4 & 15.9 & 0.00 \\
\hline All support & 380.6 & -7.5 & 51.3 & 381.1 & 424.5 & 0.11 \\
\hline \multicolumn{7}{|l|}{ New Zealand } \\
\hline Market price support & 643.0 & -2.6 & -2.8 & 526.9 & 637.6 & 1.26 \\
\hline Production subsidies & 22.2 & -0.1 & -0.1 & 21.9 & 22.0 & 0.04 \\
\hline Input subsidics & 15.8 & -0.1 & 6.3 & 22.0 & 22.1 & 0.04 \\
\hline All support & 658.4 & -2.7 & 6.3 & 543.8 & 662.0 & 1.31 \\
\hline \multicolumn{7}{|l|}{ Switzerland } \\
\hline Market price support & -1867.6 & 2057.3 & 1007.9 & 73.1 & 1197.6 & 0.50 \\
\hline Production subsidics & -467.9 & -30.8 & 799.3 & 3.0 & 300.6 & 0.12 \\
\hline Input subsidies & -15.4 & -30.9 & 51.8 & 3.0 & 5.5 & 0.00 \\
\hline All support & -1991.5 & 2045.3 & 1145.7 & 75.5 & 1199.5 & 0.50 \\
\hline \multicolumn{7}{|l|}{ Iceland } \\
\hline Marke1 price support & .73 .2 & 58.9 & 67.0 & -0.7 & 52.8 & 0.62 \\
\hline Production subsidies & .73 .7 & -1.1 & 126.3 & 0.0 & 51.6 & 0.61 \\
\hline Input subsidios & -1.4 & -1.1 & 3.2 & 0.0 & 0.8 & 0.01 \\
\hline All support & -95.3 & 58.5 & 96.5 & -0.7 & 59.7 & 0.70 \\
\hline \multicolumn{7}{|l|}{ Norway } \\
\hline Markel price support & -731.8 & 671.7 & 571.7 & 18.0 & 512.3 & 0.32 \\
\hline Production subsidies & -421.6 & -12.0 & 720.9 & 0.7 & 287.2 & 0.18 \\
\hline Inpust subsidies & .305 .4 & -12.1 & 528.0 & 0.7 & 210.5 & 0.13 \\
\hline All support & -1013.4 & 666.6 & 934.9 & 18.6 & 588.0 & 0.37 \\
\hline \multicolumn{7}{|l|}{ Canada } \\
\hline Market price support & -2417.4 & 2951.0 & .246 .7 & -59.8 & 286.9 & 0.04 \\
\hline Produclion subsidies & $-31,8$ & -61.7 & 84.7 & -2.5 & -8.9 & 0.00 \\
\hline Input subsidies & 8.6 & -61.8 & 40.0 & -2.5 & .13 .2 & 0.00 \\
\hline All support & -2488.4 & 2924.6 & -157.1 & -61.8 & 279.1 & 0.04 \\
\hline \multicolumn{7}{|l|}{ Japan } \\
\hline Market price support & .10 .6 & 3480.2 & -2603.8 & -170.5 & 865.8 & 0.02 \\
\hline Production subsidies & -0.8 & $-32,1$ & 11.1 & -7.1 & .21 .8 & 0.00 \\
\hline Input subsiditiss & 0.0 & -32.1 & 9.3 & -7.1 & -22.8 & 0.00 \\
\hline All support & -10.7 & 3467.7 & -2603.7 & -175.9 & 853.3 & 0.02 \\
\hline \multicolumn{7}{|l|}{ Korea } \\
\hline Market price support & -1.5 & 433.1 & -356.8 & -33.8 & 74.8 & 0.02 \\
\hline Production subsidieg & 0.0 & -4.8 & 1.2 & -1.4 & -3.6 & 0.00 \\
\hline Input subsidies & 0.0 & -4.8 & 1.2 & -1.4 & -3.6 & 0.00 \\
\hline Alt Support & -1.5 & 431.0 & -356.8 & -34.9 & 72.7 & 0.02 \\
\hline
\end{tabular}


Table 6. Welfare Effects of Multilateral Agricultural Trade Liberalization: Partial Equilibrium (Commodity: Rice) (In millions of 2000 U.S. Dollars, unless otherwise specified)

\begin{tabular}{|c|c|c|c|c|c|c|}
\hline & $\begin{array}{c}\text { Change in } \\
\text { Producer } \\
\text { Surplus } \\
\end{array}$ & $\begin{array}{l}\text { Change in } \\
\text { Consumer } \\
\text { Surplus }\end{array}$ & $\begin{array}{l}\text { Change in } \\
\text { Nel Govt. } \\
\text { Revenue }\end{array}$ & $\begin{array}{c}\text { Of which: } \\
\text { Tems of Trade } \\
\text { Effect }\end{array}$ & $\begin{array}{c}\text { Total Change } \\
\text { in } \\
\text { Welfare } \\
\end{array}$ & $\begin{array}{c}\text { Total Change } \\
\text { in Welfare } \\
\text { (Percent of GDP) }\end{array}$ \\
\hline \multicolumn{7}{|l|}{ United States } \\
\hline Market price support & 13.5 & -2.0 & -6.3 & 7.4 & 5.3 & 0.00 \\
\hline Production subsidies & -411.5 & -2.7 & 465.6 & 10.0 & 51.4 & 0.00 \\
\hline Input subsidies & -50.9 & -0.4 & 60.9 & 1.6 & 9.5 & 0.00 \\
\hline All support & $-447,1$ & -5.2 & 511.5 & 19.3 & 59.2 & 0.00 \\
\hline \multicolumn{7}{|l|}{ European Unjion } \\
\hline Market price support & 5.7 & -0.2 & -0.3 & 5.3 & 5.2 & 0.00 \\
\hline Production subsidies & -11.2 & -0.3 & 18.9 & 7.2 & 7.4 & 0.00 \\
\hline Input subsidies & -17.6 & 0.0 & 19.0 & 1.1 & 1.4 & 0.00 \\
\hline All support & -23.0 & +0.6 & 37.7 & 13.9 & 14.0 & 0.00 \\
\hline \multicolumn{7}{|l|}{ Australia } \\
\hline Market price support & -1.9 & 0.2 & 3.0 & 1.3 & 1.4 & 0.00 \\
\hline Production subsidies & 2.1 & -0.2 & -0.1 & 1.8 & 1.8 & 0.00 \\
\hline Input subsidies & -5.4 & -0.1 & 5.8 & 0.3 & 0.3 & 0.00 \\
\hline All support & -5.2 & -0.1 & 8.8 & 3.5 & 3.5 & 0.00 \\
\hline \multicolumn{7}{|l|}{ Japan } \\
\hline Market price support & -108.6 & 1991.3 & -1662.0 & -2.4 & 220.7 & 0.00 \\
\hline Production subsidies & -6.2 & -25.0 & 26.3 & -3.2 & -4.8 & 0.00 \\
\hline Input subsidies & -0.7 & -3.9 & 3.7 & -0.5 & -0.8 & 0.00 \\
\hline All support & -109.6 & 1985.9 & -1660.8 & -6.3 & 215.4 & 0.00 \\
\hline \multicolumn{7}{|l|}{ Korea } \\
\hline Market price support & -40.5 & 320.5 & -241.8 & -0.4 & 38.3 & $0.0 \mathrm{l}$ \\
\hline Production subsidies & 0.7 & -4.2 & 2.2 & -0.6 & -1.3 & 0.00 \\
\hline Input subsidies & -0.1 & -0.6 & 0.5 & -0.1 & -0.2 & 0.00 \\
\hline All Support & -40.5 & 319.5 & -241.7 & -1.1 & 37.3 & 0.01 \\
\hline
\end{tabular}

Source: Author's calculations. 
Table 7. Welfare Effects of Multilateral Agricultural Trade Liberalization: Partial Equilibrium (Commodity: Maize)

(In millions of 2000 U.S. Dollars, unless otherwise specified)

\begin{tabular}{|c|c|c|c|c|c|c|}
\hline & $\begin{array}{l}\text { Change in } \\
\text { Producer } \\
\text { Surplus } \\
\end{array}$ & $\begin{array}{l}\text { Change in } \\
\text { Consumer } \\
\text { Surplus } \\
\end{array}$ & $\begin{array}{l}\text { Change in } \\
\text { Net Govt. } \\
\text { Revenue }\end{array}$ & $\begin{array}{c}\text { Of which: } \\
\text { Ternns of Trade } \\
\text { Effect } \\
\end{array}$ & $\begin{array}{c}\text { Total Change } \\
\text { in } \\
\text { Welfare } \\
\end{array}$ & $\begin{array}{c}\text { Total Change } \\
\text { in Welfare } \\
\text { (Percent of GDP) }\end{array}$ \\
\hline \multicolumn{7}{|l|}{ United States } \\
\hline Market price support & 267.1 & -172.5 & -56.4 & 58.9 & 38.2 & 0.00 \\
\hline Production subsidies & -2416.5 & -182.1 & 2785.5 & 62.2 & 186.9 & 0.00 \\
\hline Input subsidies & -770.4 & -83.8 & 938.6 & 28.6 & 84.4 & 0.00 \\
\hline All support & $-2964,3$ & -23.3 & 3639.4 & 143.6 & 256.7 & 0.00 \\
\hline \multicolumn{7}{|l|}{ European Union } \\
\hline Market price support & -898.0 & 1312.5 & -306.1 & -20.4 & 108.3 & 0.00 \\
\hline Production subsidies & 75.3 & -103.2 & -11.4 & -21.5 & -39.3 & 0.00 \\
\hline Input subsidies & -263.1 & -47.3 & 329.8 & -9.9 & $\$ 9.3$ & 0.00 \\
\hline All support & -1090.2 & 1187.0 & -33.0 & -49.7 & 63.8 & 0.00 \\
\hline \multicolumn{7}{|l|}{ New Zealand } \\
\hline Market price support & 0.2 & -0.3 & 0.0 & 0.0 & 0.0 & 0.00 \\
\hline Production subsidies & 0.2 & -0.3 & 0.0 & 0.0 & 0.0 & 0.00 \\
\hline Input subsidies & 0.1 & -0.1 & 0.0 & 0.0 & 0.0 & 0.00 \\
\hline All support & 0.6 & -0.6 & 0.0 & -0.1 & 0.0 & 0.00 \\
\hline \multicolumn{7}{|l|}{ Switzerland } \\
\hline Market price support & -47.5 & 74.7 & -7.2 & -0.1 & 20.0 & 0.01 \\
\hline Production subsidies & 1.6 & -1.8 & -0.8 & -0.1 & +1.0 & 0.00 \\
\hline Input subsidies & -6.7 & -0.8 & 9.4 & -0.1 & 1.9 & 0.00 \\
\hline All support & -51.8 & 73.0 & -2.1 & -0.3 & 19.1 & 0.01 \\
\hline \multicolumn{7}{|l|}{ Canada } \\
\hline Market price support & 8.3 & -9.6 & -1.1 & -2.1 & -2.3 & 0.00 \\
\hline Production subsidies & -58.6 & -10.1 & 67.2 & -2.3 & -1.5 & 0.00 \\
\hline Input subsidies & -3.7 & -4.6 & 7.4 & -1.0 & -0.9 & 0.00 \\
\hline All support & -56.1 & -23.3 & 74.8 & -5.2 & -4.6 & 0.00 \\
\hline
\end{tabular}

Source: Author's calculations. 
Table 8. Welfare Effects of Multilateral Agricultural Trade Liberalization: Partial Equilibrium (Commodity: Cotton) (In millions of 2000 U.S. Dollars, unless otherwise specified)

\begin{tabular}{lcccccc}
\hline & $\begin{array}{c}\text { Change in } \\
\text { Producer } \\
\text { Surplus }\end{array}$ & $\begin{array}{c}\text { Change in } \\
\text { Consumer } \\
\text { Surplus }\end{array}$ & $\begin{array}{c}\text { Change in } \\
\text { Net Govt. } \\
\text { Revenue }\end{array}$ & $\begin{array}{c}\text { Of which: } \\
\text { Terms of Trade } \\
\text { Effect }\end{array}$ & $\begin{array}{c}\text { Total Change } \\
\text { in } \\
\text { Welfare }\end{array}$ & $\begin{array}{c}\text { Total Change } \\
\text { in Welfare } \\
\text { (Percent of GDP) }\end{array}$ \\
\hline United States & & & & & & \\
$\quad$ Market price support & -192.9 & 85.5 & 139.4 & 15.7 & 32.1 & 0.00 \\
Production subsidies & -813.0 & -44.1 & 936.8 & 37.4 & 79.7 & 0.00 \\
Input subsidies & na & na & na & na & na & na \\
All support & -964.5 & 43.1 & 1016.2 & 52.5 & 94.9 & 0.00 \\
\hline
\end{tabular}

Source: Author's calculations. 
Table 9. Welfare Effects of Multilateral Agricultural Trade Liberalization: Partial Equilibrium (Commodity: Sheepmeat) (In millions of 2000 U.S. Dollars, unless otherwise specified)

\begin{tabular}{|c|c|c|c|c|c|c|}
\hline & $\begin{array}{l}\text { Change in } \\
\text { Producer } \\
\text { Surplus }\end{array}$ & $\begin{array}{l}\text { Change in } \\
\text { Consumer } \\
\text { Surplus }\end{array}$ & $\begin{array}{l}\text { Change in } \\
\text { Net Govt, } \\
\text { Revenue }\end{array}$ & $\begin{array}{c}\text { Of which: } \\
\text { Terms of Trade } \\
\text { Effect }\end{array}$ & $\begin{array}{c}\text { Total Change } \\
\text { in } \\
\text { Welfare }\end{array}$ & $\begin{array}{c}\text { Total Changc } \\
\text { in Welfare } \\
\text { (Percent of GDP) }\end{array}$ \\
\hline \multicolumn{7}{|l|}{ United States } \\
\hline Market price support & 36.7 & -55.1 & -26.9 & -46.1 & -45.4 & 0.00 \\
\hline Production subsidies & -12.8 & -1.1 & 15.0 & -0.4 & 1.2 & 0.00 \\
\hline Input subsidies & -4.6 & -14.4 & 13.5 & -5.3 & -5.5 & 0.00 \\
\hline All support & 16.9 & -70.3 & 3.8 & -52.6 & -49.6 & 0.00 \\
\hline \multicolumn{7}{|l|}{ European Union } \\
\hline Market price support & -204.2 & 293.9 & -328.7 & -263.6 & -239.0 & 0.00 \\
\hline Production subsidies & 6.4 & -10.6 & -2.0 & -2.3 & -6.2 & 0.00 \\
\hline Input subsidies & -260.4 & -136.7 & 383.5 & -30.2 & -13.7 & 0.00 \\
\hline All support & -458.5 & 152.5 & 26.9 & -300.6 & -279.1 & 0.00 \\
\hline \multicolumn{7}{|l|}{ Australia } \\
\hline Market price support & 140.9 & -34.6 & -1.4 & 97.6 & 104.9 & 0.03 \\
\hline Production subsidies & 1.2 & -0.3 & 0.0 & 0.9 & 0.8 & 0.00 \\
\hline Input subsidies & -8.2 & -4.4 & 23.9 & 11.2 & 11.3 & 0.00 \\
\hline All support & 135.9 & -38.8 & 23.9 & 111.3 & 121.0 & 0.03 \\
\hline \multicolumn{7}{|l|}{ New Zealand } \\
\hline Market price support & 160.4 & -10.2 & -0.1 & 146.7 & 150.1 & 0.30 \\
\hline Production subsidies & 1.4 & -0.1 & 0.0 & 1.3 & 1.3 & 0.00 \\
\hline Input subsidies & 15.8 & -1.2 & 2.3 & 16.8 & 16.8 & 0.03 \\
\hline All support & 181.0 & -11.5 & 2.3 & 167.2 & 171.7 & 0.34 \\
\hline \multicolumn{7}{|l|}{ Switzerland } \\
\hline Market price support & -35.4 & 186.0 & -89.6 & -11.9 & 60.9 & 0.03 \\
\hline Production subsidies & 0.2 & .0 .4 & -0.2 & -0.1 & -0.5 & 0.00 \\
\hline Input subsidies & 1.1 & -5.3 & -1.5 & -1.4 & -5.6 & 0.00 \\
\hline All support & -35.4 & 179.8 & -89.2 & -13.6 & 55.3 & 0.02 \\
\hline \multicolumn{7}{|l|}{ Iceland } \\
\hline Market price support & 5.0 & -3.4 & -0.6 & 0.8 & 1.0 & 0.01 \\
\hline Production subsidies & -0.3 & 0.0 & 0.4 & 0.0 & 0.0 & 0.00 \\
\hline Input subsidies & -2.8 & -0.4 & 3.5 & 0.1 & 0.3 & 0.00 \\
\hline All support & 1.5 & -3.9 & 3.8 & 0.9 & 1.4 & 0.02 \\
\hline \multicolumn{7}{|l|}{ Norway } \\
\hline Market price support & -14.4 & 12.8 & 8.5 & -0.6 & 6.9 & 0.00 \\
\hline Production subsidies & -29.1 & -0.2 & 44.1 & 0.0 & 14.8 & 0.01 \\
\hline Input subsidies & -76.1 & -2.5 & 112.4 & -0.1 & 33.8 & 0.02 \\
\hline All support & -101.5 & 10.2 & 123.9 & -0.7 & 32.6 & 0.02 \\
\hline
\end{tabular}


Table 10. Welfare Effects of Multilateral Agricultural Trade Liberalization: Partial Equilibrium (Commodity: Wool) (In millions of 2000 U.S. Dollars, unless otherwise specified)

\begin{tabular}{|c|c|c|c|c|c|c|}
\hline & $\begin{array}{c}\text { Change in } \\
\text { Producer } \\
\text { Surplus }\end{array}$ & $\begin{array}{c}\text { Change in } \\
\text { Consumer } \\
\text { Surplus } \\
\end{array}$ & $\begin{array}{c}\text { Change in } \\
\text { Net Govt, } \\
\text { Revenue } \\
\end{array}$ & $\begin{array}{c}\text { Of which: } \\
\text { Terms of Trade } \\
\text { Effect }\end{array}$ & $\begin{array}{c}\text { Total Change } \\
\text { in } \\
\text { Welfare }\end{array}$ & $\begin{array}{c}\text { Total Change } \\
\text { in Welfare } \\
\text { (Percent of GDP) }\end{array}$ \\
\hline \multicolumn{7}{|l|}{ United States } \\
\hline Market price support & -0.3 & 1.6 & -1.3 & 0.0 & 0.0 & 0.00 \\
\hline Production subsidies & 0.0 & 0.0 & 0.0 & 0.0 & 0,0 & 0.00 \\
\hline Input subsidies & -0.3 & -0.1 & 0.3 & -0.1 & -0.1 & 0.00 \\
\hline All support & -0.6 & 1.5 & -1.0 & -0.1 & -0.1 & 0.00 \\
\hline \multicolumn{7}{|l|}{ Australia } \\
\hline Market price support & 0.3 & 0.0 & 0.0 & 0.3 & 0.3 & 0.00 \\
\hline Production subsidies & 0.1 & 0.0 & 0.0 & 0.1 & 0.1 & 0.00 \\
\hline Input subsidies & -52.1 & -0.1 & $\$ 4.2$ & 1.9 & 2.1 & 0.00 \\
\hline All support & -51.6 & -0.1 & 54.2 & 2.4 & 2.6 & 0.00 \\
\hline \multicolumn{7}{|l|}{ New Zealand } \\
\hline Market price support & 0.1 & 0.0 & 0.0 & 0.1 & 0.1 & 0.00 \\
\hline Production subsidies & 0.0 & 0.0 & 0.0 & 0.0 & 0.0 & 0.00 \\
\hline Input subsidies & 0.4 & 0.0 & 0.0 & 0.3 & 0.3 & 0.00 \\
\hline All support & 0.5 & 0.0 & 0.0 & 0.4 & 0.4 & 0.00 \\
\hline \multicolumn{7}{|l|}{ Iceland } \\
\hline Market price support & -3.9 & 3.8 & 1.0 & 0.0 & 1.0 & $0.0 \mathrm{I}$ \\
\hline Production subsidies & 0.0 & 0.0 & 0.0 & 0.0 & 0.0 & 0.00 \\
\hline Input subsidies & -0.1 & 0.0 & 0.1 & 0.0 & 0.0 & 0.00 \\
\hline All support & -4.0 & 3.8 & 1.1 & 0.0 & 1.0 & 0.01 \\
\hline \multicolumn{7}{|l|}{ Norway } \\
\hline Market price support & 0.0 & 0.0 & 0.0 & 0.0 & 0.0 & 0.00 \\
\hline Production subsidies & -14.5 & 0.0 & 17.1 & 0.0 & 2.6 & 0.00 \\
\hline Input subsidies & -13.7 & 0.0 & 16.1 & 0.0 & 2.5 & 0.00 \\
\hline All support & -26.0 & 0.0 & 29.8 & 0.0 & 3.8 & 0.00 \\
\hline
\end{tabular}

Source: Author's calculations. 
Table 11. Welfàre Effects of Multilateral Agricultural Trade Liberalization: Partial Equilibrium (Commodity: Soybeans) (In millions of 2000 U.S. Dollars, unless otherwise specified)

\begin{tabular}{|c|c|c|c|c|c|c|}
\hline & $\begin{array}{c}\text { Change in } \\
\text { Producer } \\
\text { Surplus } \\
\end{array}$ & $\begin{array}{l}\text { Change in } \\
\text { Consumer } \\
\text { Surplus }\end{array}$ & $\begin{array}{l}\text { Change in } \\
\text { Net Govt. } \\
\text { Revenue }\end{array}$ & $\begin{array}{c}\text { Of which: } \\
\text { Terms of Trade } \\
\text { Effect }\end{array}$ & $\begin{array}{c}\text { Total Change } \\
\text { in } \\
\text { Welfare } \\
\end{array}$ & $\begin{array}{c}\text { Total Change } \\
\text { in Welfare } \\
\text { (Percent of GDP) }\end{array}$ \\
\hline \multicolumn{7}{|l|}{ United States } \\
\hline Market price support & 160.1 & -71.7 & -54.8 & 52.9 & 33.6 & 0.00 \\
\hline Production subsidies & -3110.3 & -130.4 & 3570.3 & 96.6 & 329.6 & 0.00 \\
\hline Input subsidies & -545.8 & -36.7 & 672.7 & 27.0 & 90.2 & 0.00 \\
\hline All support & -3519.5 & -227.2 & 4136.9 & 169.2 & 390.2 & 0.00 \\
\hline \multicolumn{7}{|l|}{ European Union } \\
\hline Market price support & -118.6 & 270.0 & -175.5 & -33.3 & -24.1 & 0.00 \\
\hline Production subsidies & 33.2 & -114.8 & 16.5 & -60.8 & -65.1 & 0.00 \\
\hline Input subsidies & -339.3 & -32.2 & 368.9 & -17.0 & -2.6 & 0.00 \\
\hline All support & -427.3 & 136.4 & 197.4 & -106.5 & -93.4 & 0.00 \\
\hline \multicolumn{7}{|l|}{ Australia } \\
\hline Market price support & 3.6 & -3.5 & -0.2 & 0.0 & -0.1 & 0.00 \\
\hline Production subsidies & 2.1 & -6.3 & 4.2 & 0.1 & 0.0 & 0.00 \\
\hline Input subsidies & -8.0 & -1.8 & 9.9 & 0.0 & 0.2 & 0.00 \\
\hline All support & -2.9 & -11.0 & 14.2 & 0.1 & 0.2 & 0.00 \\
\hline \multicolumn{7}{|l|}{ Switzerland } \\
\hline Market price support & -90.8 & 253.4 & -80.3 & -0.2 & 82.3 & 0.03 \\
\hline Production subsidies & 2.6 & -4.5 & -0.9 & -0.4 & -2.8 & 0.00 \\
\hline Input subsidies & -3.9 & -1.3 & 5.8 & -0.1 & 0.7 & 0.00 \\
\hline All support & -93.0 & 251.1 & .77 .6 & -0.8 & 80.4 & 0.03 \\
\hline \multicolumn{7}{|l|}{ Canada } \\
\hline Market price support & 16.4 & -14.4 & -0.2 & 1.8 & 1.7 & 0.00 \\
\hline Production subsidies & 20.1 & -26.3 & 9.5 & 3.3 & 3.4 & 0.00 \\
\hline Input subsidies & -23.7 & -7.4 & 32.1 & 0.9 & 1.0 & 0.00 \\
\hline All support & 10.4 & -45.7 & 41.7 & 5.7 & 6.4 & 0.00 \\
\hline \multicolumn{7}{|l|}{ Japan } \\
\hline Market price support & 0.0 & -12.2 & 0.0 & -12.2 & -12.2 & 0.00 \\
\hline Production subsidies & -0.1 & -22.2 & 0.2 & -22.3 & -22.1 & 0.00 \\
\hline Input subsidies & -0.1 & -6.2 & 0.1 & -6.2 & -6.2 & 0.00 \\
\hline All support & -0.1 & -38.7 & 0.2 & -39.0 & -38.7 & 0.00 \\
\hline \multicolumn{7}{|l|}{ Korea } \\
\hline Market price support & -1.6 & 4130.4 & -2980.1 & -3.3 & 1148.6 & 0.25 \\
\hline Production subsidies & 0.1 & -60.0 & 32.3 & -6.0 & -27.6 & -0.01 \\
\hline Input subsidies & 0.0 & -16.8 & 9.1 & -1.7 & -7.7 & 0.00 \\
\hline All Support & -1.6 & 4112.4 & .2980 .1 & -10.5 & 1130.7 & 0.25 \\
\hline
\end{tabular}

Source: Author's calculations. 
Table 12. Welfare Effects of Multilateral Agricultural Trade Liberalization: Partial Equilibrium (Commodity: Refined Sugar) (In millions of 2000 U.S. Dollars, unless otherwise specified)

\begin{tabular}{|c|c|c|c|c|c|c|}
\hline & $\begin{array}{l}\text { Change in } \\
\text { Producer } \\
\text { Surplus } \\
\end{array}$ & $\begin{array}{l}\text { Change in } \\
\text { Consumer } \\
\text { Surplus } \\
\end{array}$ & $\begin{array}{l}\text { Change in } \\
\text { Net Govt. } \\
\text { Revenue }\end{array}$ & $\begin{array}{c}\text { Of which: } \\
\text { Terms of Trade } \\
\text { Effect }\end{array}$ & $\begin{array}{c}\text { Total Change } \\
\text { in } \\
\text { Welfure }\end{array}$ & $\begin{array}{c}\text { Total Change } \\
\text { in Welfare } \\
\text { (Percent of GDP) }\end{array}$ \\
\hline \multicolumn{7}{|l|}{ United States } \\
\hline Market price support & -1282.1 & 1415.5 & 32.6 & -3.3 & 0.0 & 0.00 \\
\hline Production subsidies & -105.7 & -2.8 & 122.1 & 0.0 & 13.6 & 0.00 \\
\hline Input subsidies & -105.0 & -5.8 & 123.9 & -0.1 & 13.1 & 0.00 \\
\hline All support & -1435.6 & 1411.6 & 190.7 & -3.7 & 166.8 & 0.00 \\
\hline \multicolumn{7}{|l|}{ European Union } \\
\hline Market price support & -8890.3 & 8368.6 & 3478.4 & 114.8 & 2956.6 & 0.04 \\
\hline Production subsidies & -69.5 & -8.1 & 96.4 & l.1 & 18.9 & 0.00 \\
\hline Input subsidies & -128.4 & -17.0 & 180.1 & 2.3 & 34.7 & 0.00 \\
\hline All support & -9000.7 & 8361.1 & 3594.5 & 117.2 & 2954,9 & 0.04 \\
\hline \multicolumn{7}{|l|}{ Australia } \\
\hline Market price support & 23.1 & -20.6 & -0.5 & 2.8 & 2.0 & 0.00 \\
\hline Production subsidies & 0.3 & -0.3 & 0.0 & 0.0 & 0.0 & 0.00 \\
\hline Input subsidies & -37.0 & -0.6 & 39.0 & 0.1 & 1.5 & 0.00 \\
\hline All support & -15.1 & -21.1 & 39.3 & 2.8 & 3.1 & 0.00 \\
\hline \multicolumn{7}{|l|}{ Switzerland } \\
\hline Market price support & -220.5 & 421.7 & -95.2 & -2.7 & 106.0 & 0.04 \\
\hline Production subsidies & 0.3 & -0.4 & -0.1 & 0.0 & -0.2 & 0.00 \\
\hline Input subsidies & -7.1 & -0.8 & 9.7 & -0.1 & 1.9 & 0.00 \\
\hline All support & -225.1 & 421.4 & -90.5 & $-2,8$ & 105.8 & 0.04 \\
\hline \multicolumn{7}{|l|}{ Japan } \\
\hline Market price support & -0.9 & 36.9 & -26.5 & -0.2 & 9.6 & 0.00 \\
\hline Production subsidies & -0.1 & 0.0 & 0.2 & 0.0 & 0.1 & 0.00 \\
\hline Input subsidies & 0.0 & -0.1 & 0.1 & 0.0 & 0.0 & 0.00 \\
\hline All support & -0.9 & 36.9 & -26.5 & -0.2 & 9.6 & 0.00 \\
\hline
\end{tabular}

Source: Author's calculations. 
rather than all forms of support. In the case of wheat, simultaneous removal of all production subsidies, while keeping all other forms of support in place, would reduce welfare in the EU by about US $\$ 39$ million. This is because the principal distortion that the EU has in place on wheat is export subsidies. When all countries remove their production subsidies, the world price rises. With export subsidies in place, the increase in the world price leads to an expansion in output of a subsidized product in the EU, which worsens welfare; the increase in the world price exacerbates the existing distortion (export subsidy). This result, which follows from equation (3), makes the point that the form of agricultural support matters. Liberalization should be undertaken as a complete package-removal of all forms of support-rather than a piecmeal approach that includes only certain types of support.

Not surprisingly, the simulations confirm that "market-price" support, i.e. tariffs and export subsidies, have the largest distortionary impact of the four types of support considered. This result is similar to the findings of Hoekman et al. (2002), who conclude that tariff removal produces larger welfare gains than subsidy removal. Although nearly all countries apply input subsidies, these have relatively small effects on welfare and world prices, compared to the other types of support. There are some exceptions to this general result and they occur mainly in the case of the United States, which relies more heavily on production and input subsidies. For example, in the case of rice and maize, the United States gains substantially more from removal of production subsidies, compared to the gains from removing market price support.

In general, the magnitude of the increases in world prices is largest when marketprice support is removed, although there are some exceptions to this (Table 2), depending on the product and the degree of support. For five of the ten commodities, the increase in the world price is largest when market-price support is removed. For three commodities (rice, cotton, and soybeans), the world price increases the most as a result of removing production subsidies, reflecting the relatively high levels of domestic support applied to these commodities in the United States. The largest increase in the world price from liberalization occurs in milk and milk products, given the very high degree of support in place across countries.

\section{B. Impact of Multilateral Liberalization on Net-Food-Importing Countries}

A major concern expressed by a number of developing countries in the Uruguay Round was the potential negative impact agricultural liberalization might have on net-foodimporting countries (NFICs). Removal of agricultural support would likely raise the international prices of food, leading to higher import costs for countries that rely on imported food. In response to this concern, the Uruguay Round Agreement on Agriculture included the 
Marrakesh Decision. ${ }^{7}$ Using the estimated changes in the world prices presented above, this section presents estimates of the increases in import costs resulting from the world price increases. The change in import costs by country is calculated by applying the change in the world price that results from liberalization and an import demand elasticity (mentioned in Section IV) to the quantity of net imports of each commodity in 2000.

Table 13 presents the effects on import bills for the 79 countries designated as netfood importing by the WTO, broken down by commodity. Several results emerge. First, and most striking, import costs do not increase for all countries. While nearly all countries in table 13 are net importers of grains (wheat and maize), a number of countries are exporters of other supported products, such as cotton, refined sugar, and rice. For a number of countries, (e.g. Uzbekistan, Pakistan, and Cote d'Ivoire), the gain in export revenue actually offsets the increase in import costs across all ten commodities. Broad-based liberalization will therefore not lead to higher import costs for all countries. If liberalization were limited to grains, more countries would face higher import costs.

While all of the countries on the list have been designed as net-food importers, there are differences across these countries in terms of their net-trade positions in various commodities. Table 13 shows that a number of countries from several regions, although mainly those in the Middle East and North Africa, would be adversely affected by liberalization in grains (wheat and maize). For these two commodities alone, the largest increases in their import bills (in US\$ millions) would be felt by Egypt (\$11.4), Mexico (\$6.7), Morocco (\$5.7), Philippines (\$4.3), Syria (\$3.6), Russia (\$3.2), Venezuela (\$2.8), Peru (\$2.4), Bangladesh (\$2.2), Nigeria and Yemen each (\$2.1), and United Arab Emirates (\$2.0). Many small, island economies (e.g. Maldives, Samoa, Sri Lanka, the islands of the Eastern Caribbean, Cape Verde, Seychelles, and Tonga), as well as Venezuela, the Philippines, the Dominican Republic, and Singapore would experience relatively large increases in import costs in percentage terms, reflecting their dependence on grain imports.

Second, for the countries that do experience an increase in their import costs, these increases are less than 2 percent of total affected imports, although nine countries would experience increases in excess of US\$10 million. Six countries-Dominica, Lebanon, Maldives, Trinidad and Tobago, Laos, and Samoa-would experience an increase in import costs exceeding 3 percent of affected imports. These results are broadly similar to those of Eiteljörge and Shiells (1995), who calculated the increase in net food-import costs as a result of the Uruguay Round and found that they would likely be less than 4 percent of net food

\footnotetext{
7 The "Marrakesh Decision" refers to the Decision on Measures Concerning the Possible Negative Effects of the Reform Program on Least-Developed and Net-Food Importing Developing Countries. The "Decision" states that countries that experience increases in food import costs could draw on existing financial resources of international financial institutions, or a new financing facility could be created. The countries eligible for financing enumerated in the Decision include the 49 countries that are classified as least developed by the United Nations, plus an additional 23 net-food-importing countries (see WTO, 2002).
} 
Table 13. Increase in Import Costs as a Result of Removing Agricultural Support in Developed Countries (In millions of 2000 U.S. dollars)

\begin{tabular}{|c|c|c|c|c|c|c|c|c|c|c|c|}
\hline & & & & & & & & & Refined & & \\
\hline & Wheal & Maizc & Rice & Becf & Milk & Cotton & Wool & Shecpmcat & Sugar & Soybcans & Total \\
\hline Afghanistan & na & na & na & na & na & na & па & nа & na & na & па \\
\hline Angola & 0.42 & 0.12 & 0.05 & 0.10 & 0.43 & 0.00 & 0.00 & 0.01 & 0.37 & 0.00 & 1.49 \\
\hline Bangladesh & 2.10 & 0.08 & 0.71 & 0.00 & 4.88 & 3.61 & 0.01 & 0.28 & 0.00 & 0.00 & 11.67 \\
\hline Barbados & 0.02 & 0.03 & 0.03 & 0.03 & 0.54 & -0.02 & 0.00 & 0.12 & 0.0 .3 & 0.04 & 0.82 \\
\hline Benin & 0.10 & 0.00 & 0.14 & 0.01 & 0.17 & -6.42 & 0.00 & 0.00 & 0.16 & 0.00 & -5.84 \\
\hline Bhutan & 0.01 & 0.01 & 0.01 & 0.00 & 0.10 & 0.00 & 0.00 & 0.00 & 0.01 & -0.05 & 0.09 \\
\hline Botswana & 0.17 & 0.10 & 0.16 & -3.31 & 1.57 & 0.12 & 0.00 & 0.03 & 0.23 & 0.01 & -0.93 \\
\hline Burkina Faso & 0.08 & -0.02 & 0.17 & 0.00 & 0.47 & -5.34 & 0.00 & 0.00 & 0.12 & 0.00 & -4.53 \\
\hline Burundi & 0.04 & 0.02 & 0.01 & 0.00 & 0.09 & 0.00 & 0.00 & 0.00 & 0.01 & 0.00 & 0.18 \\
\hline Cambodia & 0.07 & -0.01 & 0.04 & 0.00 & 0.54 & 0.01 & 0.00 & 0.00 & 0.12 & -0.39 & 0.38 \\
\hline Cape Verde & 0.03 & 0.02 & 0.04 & 0.00 & 0.44 & 0.00 & 0.00 & 0.00 & 0.08 & 0.00 & 0.61 \\
\hline Central African Republic & 0.05 & 0.00 & 0.00 & 0.00 & 0.03 & -0.70 & 0.00 & 0.00 & 0.03 & 0.00 & -0.59 \\
\hline Chad & 0.07 & 0.00 & $0.0 \mathrm{t}$ & 0.00 & 0.18 & -4.34 & 0.00 & 0.00 & 0.28 & 0.00 & -3.79 \\
\hline Comoros & 0.01 & 0.00 & 0.03 & 0.01 & 0.05 & 0.00 & 0.00 & 0.00 & 0.01 & 0.00 & 0.11 \\
\hline Congo, Dem Republic of & 0.23 & 0.01 & 0.02 & 0.04 & 0.22 & 0.21 & 0.00 & 0.00 & 0.02 & 0.00 & 0.76 \\
\hline Cóte d'Ivoire & 0.40 & 0.01 & 0.56 & 0.02 & 1.36 & -30.53 & 0.00 & 0.01 & -14.60 & 0.01 & -22.75 \\
\hline Cuba & 1.48 & 0.09 & 0.58 & 0.00 & 4.66 & 0.01 & 0.00 & 0.00 & 0.00 & 0.03 & 6.85 \\
\hline Djibouli & 0.05 & 0.00 & 0.03 & 0.00 & 0.77 & 0.00 & 0.00 & 0.00 & -5.99 & 0.00 & -5.13 \\
\hline Dominica & 0.02 & 0.00 & 0.00 & 0.00 & 0.18 & 0.00 & 0.00 & 0.00 & 0.02 & 0.00 & 0.23 \\
\hline Dominican Republic & 0.36 & 0.47 & 0.10 & 0.00 & 2.32 & 0.05 & 0.00 & 0.02 & -8.99 & 0.00 & -5.68 \\
\hline Egypt & 6.95 & 4.41 & -6.57 & 1.04 & 8.12 & -8.78 & 0.00 & 0.12 & 0.21 & 0.42 & 5.92 \\
\hline Equatorial Guinca & 0.02 & 0.00 & 0.00 & 0.00 & 0.04 & 0.00 & 0.00 & 0.00 & 0.01 & 0.00 & 0.08 \\
\hline Eritrea & 0.24 & 0.00 & 0.00 & 0.00 & 0.25 & 0.00 & 0.00 & 0.00 & 0.03 & 0.00 & 0.52 \\
\hline Ethiopia & 1.63 & 0.01 & 0.01 & 0.00 & 0.14 & $-0.4 !$ & 0.00 & -1.53 & 0.15 & 0.00 & -0.01 \\
\hline Gambia & 0.05 & 0.00 & 0.00 & 0.00 & 0.18 & $-0.0 !$ & 0.00 & 0.00 & 0.27 & 0.00 & 0.49 \\
\hline Guinca & 0.18 & 0.00 & 0.16 & 0.00 & 0.80 & -0.40 & 0.00 & 0.00 & 0.26 & 0.09 & 1.00 \\
\hline Guinea-Bissau & 0.01 & 0.00 & $0.0 \%$ & 0.00 & 0.05 & -0.09 & 0.00 & 0.00 & 0.08 & 0.00 & 0.15 \\
\hline Haiti & 0.28 & 0,00 & 0.45 & 0.00 & 1.46 & 0.00 & 0.00 & 0.00 & 0.10 & 0.00 & 2.29 \\
\hline Honduras & 0.31 & 0.21 & 0.10 & 0.01 & 1.02 & 0.03 & 0.00 & 0.01 & 0.10 & 0.00 & 1.79 \\
\hline Jamaica & 0.38 & 0.14 & 0.10 & 0.04 & 1.61 & 0.00 & 0.00 & 0.41 & 0.58 & 0.00 & 3.27 \\
\hline Jordan & 0.92 & 0.37 & 0.22 & 0.13 & 3.29 & 0.02 & 0.03 & 0.84 & 0.88 & 0.02 & 6.73 \\
\hline Kenya & 121 & 0.58 & 0.19 & 0.00 & 0.22 & 0.01 & -0.06 & 0.01 & 0.77 & 0.01 & 2.93 \\
\hline Kiribati & 0.01 & 0.00 & 0.01 & 0.00 & 0.04 & 0.00 & 0.00 & 0.00 & 0.00 & 0.00 & 0.07 \\
\hline Laos & 0.00 & 0.60 & 0.02 & 0.00 & 0.38 & 0.00 & 0.00 & 0.00 & 0.10 & 0.00 & 0.51 \\
\hline Lebanon & 0.38 & 0.22 & 0.10 & 0.14 & 6.96 & 0.01 & 0.00 & 0.02 & 0.38 & 0.02 & 8.23 \\
\hline Lesotho & 0.04 & 0.16 & 0.01 & 0.00 & 0.28 & 0.00 & 0.00 & 0.00 & 0.18 & 0.00 & 0.66 \\
\hline Liberia & 0.12 & 0.04 & 0.05 & 0.01 & 0.15 & 0.00 & 0.00 & 0.00 & 0.05 & 0.00 & 0.43 \\
\hline Madagascar & 0.15 & .0 .08 & 0.23 & 0.00 & 0.34 & -0.03 & 0.02 & 0.00 & 0.06 & 0.00 & 0.70 \\
\hline Malawi & 0.05 & 0.00 & -0.01 & 0.00 & 0.18 & -0.26 & 0.00 & 0.00 & -3.86 & 0.19 & -3.71 \\
\hline Maldives & 0.01 & 0.00 & 0.00 & 0.00 & 0.40 & 0.00 & 0.00 & 0.02 & 0.02 & 0.00 & 0.45 \\
\hline Mali & 0.10 & 0.00 & 0.05 & 0.00 & 0.88 & -9.16 & 0.00 & 0.00 & 0.32 & 0.00 & -7.81 \\
\hline Mauritania & 0.27 & 0.00 & 0.07 & 0.00 & 0.65 & 0.00 & 0.00 & 0.00 & 0.00 & 0.00 & 1.00 \\
\hline Mauritius & 0.13 & 0.06 & 0.14 & 0.04 & 2.19 & 0.25 & 0.00 & 0.41 & 0.00 & 0.00 & 3.24 \\
\hline Mexico & 2.51 & 4.15 & 0.58 & 3.22 & 31.83 & 7,01 & 0.60 & 2.38 & -37.63 & 6.16 & 20.22 \\
\hline
\end{tabular}


Table 13 (Concluded). Increase in Import Costs as a Result of Removing Agricultural Support in Developed Countries (In millions of 2000 U.S. dollars)

\begin{tabular}{|c|c|c|c|c|c|c|c|c|c|c|c|}
\hline & Wheat & Maize & Rice & Beef & Milk & Cotton & Wool & Sheepmeat & $\begin{array}{c}\text { Refined } \\
\text { Sugar }\end{array}$ & Soybeans & Total \\
\hline Moroceo & 4.84 & 0.82 & 0.01 & 0.01 & 2.61 & 0.63 & 0.00 & 0.01 & 0.04 & 0.38 & 9.35 \\
\hline Mozambique & 0.22 & 0.20 & 0.12 & 0.01 & 0.79 & -0.59 & 0.00 & 0.00 & 0.68 & 0.00 & 1.44 \\
\hline Myanmar & 0.17 & -0.98 & -0.62 & 0.00 & 0.52 & 0.00 & 0.00 & 0.00 & 0.03 & -0.58 & -1.45 \\
\hline Nepal & 0.00 & 0.00 & 0.24 & 0.00 & 0.08 & 0.11 & 0.00 & 0.00 & 0.21 & 0.00 & 0.64 \\
\hline Niger & 0.08 & 0.02 & 0.14 & 0.00 & 0.47 & -0.02 & 0.00 & 0.000 & 0.27 & 0.00 & 0,97 \\
\hline Nigeria & 2.42 & -0.35 & 1.19 & 0.00 & 6.50 & 0.27 & 0.00 & 0.00 & 1.76 & -0.46 & 11.33 \\
\hline Pakistan & 1.29 & 0.06 & -31.32 & -0.07 & 0.87 & -8.83 & 0.00 & -3.75 & 4.11 & 0.03 & -37.62 \\
\hline Peru & 1.69 & 0.70 & 0.15 & 0.02 & 3.55 & 0.50 & 0.00 & 0.02 & 0.88 & 0.05 & 7.57 \\
\hline Philippines & 3.81 & 0.49 & 0.78 & 0.45 & 21.37 & 0.78 & 0.00 & 0.03 & 1.04 & 0.88 & 29,64 \\
\hline Russian Federation & 2.21 & 0.95 & 0.37 & 1.53 & 4.60 & 5,32 & 0.00 & 0.19 & 0.72 & -0.29 & 15.59 \\
\hline Rwanda & 0.01 & 0.02 & 0.60 & 0.00 & 0.06 & 0.00 & 0.00 & 0.00 & 0.02 & 0.00 & 0.12 \\
\hline Saint Kilts and Nevis & 0.01 & 0.00 & 0.00 & 0.00 & 0.11 & 0.00 & 0.00 & 0.01 & 0.01 & 0.00 & 0.14 \\
\hline Saint Lucia & 0.06 & 0.00 & 0.02 & 0.01 & 0.47 & 0.00 & 0.00 & 0.05 & 0.01 & 0.00 & 0.62 \\
\hline Saint Vincent/Grenadines & 0.03 & 0.00 & -0.18 & 0.00 & 0.15 & 0.00 & 0.00 & 0.01 & 0.01 & 0.00 & 0.00 \\
\hline Samoa & 0.00 & 0.00 & 0.00 & 0.00 & 0.08 & 0.00 & 0.00 & 0.10 & 0.01 & 0.00 & 0.19 \\
\hline Sao Tome and Principe & 0.01 & 0.00 & 0.01 & 0.00 & 0.02 & 0.00 & 0.00 & 0.00 & 0.01 & 0.00 & 0.05 \\
\hline Saudi Arabia & 0.06 & 1.29 & 2.82 & 0.39 & 24.53 & 0.01 & 0.00 & 5.78 & 0.53 & 0.02 & 35.43 \\
\hline Senegal & 0.33 & 0.02 & 0.63 & 0.00 & 1.67 & -0.43 & 0.00 & 0.01 & 0.55 & 0.00 & 2.37 \\
\hline Seychelles & 0.02 & 0.00 & 0.03 & 0.01 & 0.29 & 0.00 & 0.00 & 0.02 & 0.03 & 0.00 & 0.41 \\
\hline Sierra Leone & 0.05 & 0.00 & 0.40 & 0.00 & 0.17 & 0.00 & 0.00 & 0.00 & 0.07 & 0.00 & 0.70 \\
\hline Singapore & 0.40 & 0.03 & 0.75 & 0.24 & 8.62 & 0.05 & 0.00 & 0.87 & 0.66 & 0.06 & 11.68 \\
\hline Solomon Islands & 0.02 & 0.00 & 0.05 & 0.80 & 0.04 & 0.00 & 0.00 & 0.00 & 0.01 & 0.00 & 0.13 \\
\hline Somalia & 0.08 & 0.02 & 0.07 & 0.00 & 0.08 & 0.00 & 0.00 & 0.00 & 0.61 & 0.00 & 0.85 \\
\hline Sri Lanka & 1.21 & 0.11 & 0.01 & -0.01 & 6.34 & 0.15 & -0.81 & 0.06 & 2.19 & 0.01 & 9.26 \\
\hline Sudan & 1.25 & 0.00 & 0.04 & -0.44 & 0.67 & -1.80 & 0.01 & -9.79 & 2.30 & 0.00 & -7.75 \\
\hline Syrian Arab Republic & 0.17 & 3.40 & 1.36 & 0.00 & 10.99 & -18.90 & 0.01 & 0.00 & 6.69 & 0.48 & 4.19 \\
\hline Tajikistan & 0.90 & 0.00 & 0.02 & 0.11 & 0.10 & -6.20 & 0.00 & 0.00 & 0.02 & 0.00 & -5.04 \\
\hline Tanzania, United Rep of & 0.37 & 0.07 & 0.10 & 0.00 & 0.19 & -0.91 & 0.00 & 0.01 & 0.23 & 0.00 & 0.06 \\
\hline Togo & 0.06 & 0.00 & 0.01 & 0.00 & 0.04 & -3.02 & 0.74 & 0.00 & 0.02 & 0.00 & -2.15 \\
\hline Tonga & 0.02 & 0.00 & 0.00 & 0.01 & 0.10 & 0.00 & 0.00 & 0.09 & 0.01 & 0.00 & 0.23 \\
\hline Trinidad and Tobago & 0.19 & 0.06 & 0.03 & 0.05 & 2.01 & 0.00 & 0.00 & 0.15 & 0.51 & 0.14 & 3.14 \\
\hline Tunisia & 1.29 & 0.53 & 0.02 & 0.03 & 0.70 & 0.49 & 0.00 & 0.00 & 0.61 & 0.00 & 3.67 \\
\hline Turkmenistan & 0.04 & 0.01 & 0.00 & 0.02 & 1.47 & -7.68 & 0.02 & 0.00 & 0.00 & 0.00 & -6.13 \\
\hline Tuvalu & 0.00 & 0.20 & 0.00 & 0.00 & $0.0 \mathrm{l}$ & 0.00 & 0.00 & 0.00 & 0.00 & 0.00 & 0.01 \\
\hline Uganda & 0.26 & 0.02 & 0.09 & 0.00 & 0.03 & -1.61 & 0.00 & 0.00 & 0.19 & 0.00 & -1.02 \\
\hline United Arab Emirates & 1.92 & 0.11 & 0.62 & 0.03 & 8.44 & 0.01 & 0.00 & 1.80 & 0.22 & 0.00 & 13.15 \\
\hline Uzbekistan & 0.61 & 0.00 & 0.14 & 0.75 & 0.27 & -60.52 & 0.00 & 0.00 & 1.64 & 0.45 & -56.65 \\
\hline Vanuatu & 0.00 & 0.00 & 0.03 & -0.18 & 0.06 & 0.60 & -0.05 & 0.00 & 0.02 & 0.00 & -0.12 \\
\hline Venezuela, Boliv Rep of & 1.62 & 1.14 & -1.09 & 0.02 & 9.52 & 0.52 & 0.00 & 0.01 & 0.05 & 0.33 & 12.12 \\
\hline Yernen & 1.97 & 0.16 & 0.39 & 0.02 & 4.14 & -0.25 & 0.00 & 0.00 & 1.86 & 0.05 & 8.34 \\
\hline Zambia & -0.17 & 0.00 & 0.01 & 0.00 & 0.09 & -0.70 & 0.00 & 0.00 & -2.65 & 0.00 & -3.42 \\
\hline
\end{tabular}

Source: Author's calculations 
imports over a six-year period. The increases in import costs are influenced to a large degree by the sharp rise in the world price of milk following liberalization. Indeed, for many of the net-food importing countries, the increase in the cost of imported milk makes up more than three quarters of the increase in total import costs. In addition, many of these countries constitute some of the world's poorest countries (e.g. Mali).

This fact should not deter liberalization of agricultural commodities, nor argue for a selective approach where certain sensitive products, such as milk, would be exempt from liberalization commitments. Rather, these results show that in the process of liberalization, greater attention needs to be paid to designing compensation schemes that will make comprehensive liberalization more attractive to all parties. Furthermore, while many poor countries might have to pay more for imported food as a result of liberalization, some of these costs would be offset if liberalization of non-food products is considered. For example, many poor countries of West Africa and Central Asia, are net exporters of cotton. Removal of support to the cotton sector in industrial countries would raise the world price and increase the export earnings of these countries, offsetting some of the increase in the cost of food imports that would result from liberalization. The gains in export revenue from liberalization of cotton are particularly large for Benin, Burkina Faso, Côte d'Ivoire, Mali, Pakistan, Syria, and Uzbekistan.

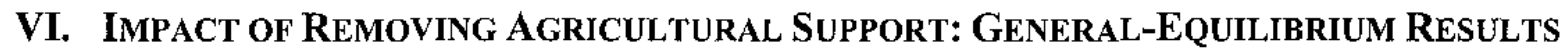

The previous section discussed the impact of removing agricultural support in the context of a partial-equilibrium model in which interactions across commodities and income effects are ignored. To gain some perspective on the importance of taking into account feedback effects across countries and commodities, this section presents some estimates of the impact of removing agricultural support in both developed and developing countries, using a world general equilibrium model. To assess the impact of industrial country interventions in agriculture on the targeted sector, as well as other sectors of the economy, a world general equilibrium model, GTAP (Global Trade Analysis Project) ${ }^{8}$ is used. GTAP explicitly simulates the behavior of sixty-six regions of the world and fifty-five commodities. The model solves for a set of prices that satisfies a number of conditions for equilibrium, such as market clearing and full employment. The model uses actual data on production, consumption, imports, exports, and tax and trade policies (i.e. tariffs and subsidies) for all countries and regions, benchmarked to 1997.

There are trade-offs in the choice between using a partial-equilibrium model or a general equilibrium to assess the effects of policy changes. The main advantage of the partial-equilibrium framework is that it exposes the major factors influencing the result, and is transparent, but feedback effects of policy changes are not taken into account. The general equilibrium model captures the feedback effects across sectors and countries, but it is more complex and requires substantially more data. Therefore, both approaches have been used in this paper to look at the impact of agricultural support from different perspectives.

\footnotetext{
${ }^{8}$ For complete documentation of the GTAP modeling framework, see Hertel, ed. (1997).
} 
Starting from the 1997 base, the model was used to conduct three experiments: (i) tariff removal; (ii) subsidy removal; and (iii) tariff and subsidy removal. Each of these three experiments were conducted for three cases: (i) global liberalization; (ii) developed country liberalization only; and (ii) developing country liberalization only. For the purposes of these experiments, developed countries include Australia, New Zealand, Canada, the United States, the fifteen countries of the EU, Japan, Korea, and other member countries of the OECD, while all other countries are considered developing countries. Trade interventions were removed in the following product categories: rice, meat, dairy, cotton, wheat, grains, sugar, and soybeans. Tables 14 and 15 present the welfare effects of these various scenarios.

Liberalization of agricultural trade by both developed and developing countries would raise real incomes in all countries by US $\$ 128$ billion or 0.4 percent of world GDP (Table 14). The distinctive feature of this experiment is that no country or region loses from global liberalization-everyone has something to gain from liberalization. The largest gainers are the regions with the most distorting barriers: the EU and Japan. Developed countries as a group reap over 75 percent of the gains, reflecting the fact that agricultural support is highest in these countries. Even though Australia and New Zealand have relatively low distortions, they benefit from global liberalization because their terms of trade improve. These results suggest that if all countries could be induced to remove the support they provide to the agricultural sector, every country would benefit. The benefits arise because of a more efficient allocation of resources and consumers pay lower prices for agricultural products.

Distortions imposed by developing countries are no trivial matter. Indeed, while these countries have few trade-distorting subsidies in place, they do maintain tariff barriers against exports from developed countries, as well as high tariffs against imports from other developing countries, and these tariffs are generally higher than developed country tariffs. As Table 14 shows, removal of developing country tariffs and subsidies on agricultural products would result in an aggregate welfare gain of about US\$24 billion for all countries, and about 88 percent of these gains would accrue to developing countries themselves. The Middle East and North Africa alone would gain the most (US\$10 billion), as their agricultural tariffs are quite high on wheat, vegetables, dairy, meat, and beverages. Developed countries, including the United States, Australia, New Zealand, and Canada, would also gain, since these countries are major exporters of agricultural products and their terms of trade improve. The only region that would lose would be the EU, because liberalization by developing countries would raise world prices of agricultural products, providing an incentive for the EU to increase exports. Since the EU already has export subsidies in place, its exports of agricultural products exceed the optimal amount. Therefore, the rise in the world price worsens the distortionary effect of the EU's export subsidies. This effect, as demonstrated by application of equation (3), arose in the partial-equilibrium simulations as well.

Complete agricultural liberalization by developed countries alone would confer a welfare gain on all countries of about US $\$ 100$ billion at 1997 prices (Table 14). Most regions of the world gain from liberalization, including many developing countries, with the largest 
Tablc 14. Welfare Effects of Agricultural Liberalization (In millions of 1997 U.S. dollars)

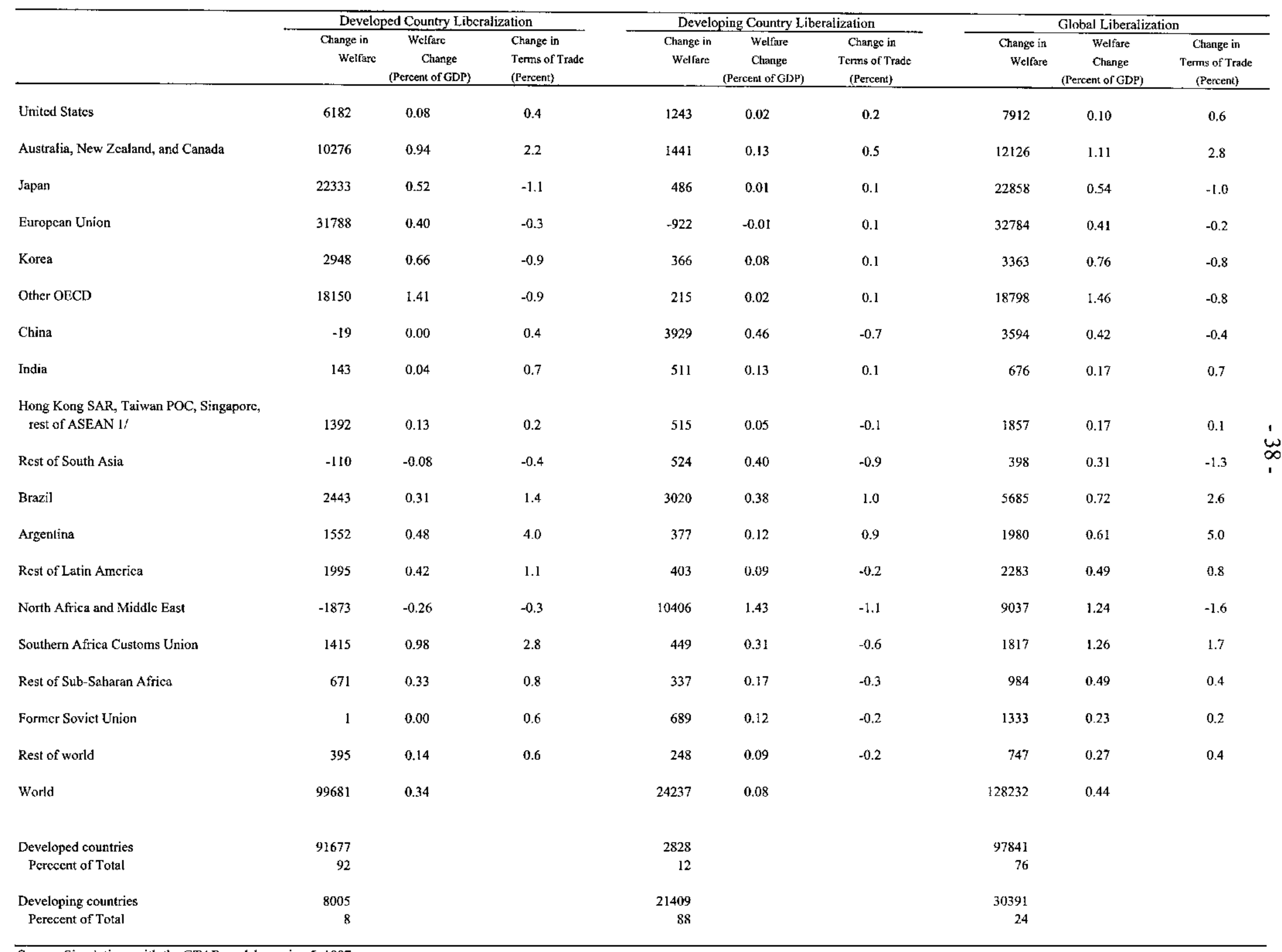

Source: Simulations with the GTAP model, version 5, 1997. 
Table 15. Welfare Effects of Agricultural Libcralization by Developed Countries (In millions of 1997 U.S. dollars)

\begin{tabular}{|c|c|c|c|c|c|c|c|c|c|}
\hline & \multicolumn{3}{|c|}{ Tariff Removal } & \multicolumn{3}{|c|}{ Subisdy Removal } & \multicolumn{3}{|c|}{ Tariff and Subsidy Removal } \\
\hline & $\begin{array}{l}\text { Charge in } \\
\text { Welfare }\end{array}$ & $\begin{array}{c}\text { Welfare } \\
\text { Change } \\
\text { (Percent of GDP) }\end{array}$ & $\begin{array}{c}\text { Change in } \\
\text { Terms of Trade } \\
\text { (Percent) }\end{array}$ & $\begin{array}{l}\text { Change in } \\
\text { Welfare }\end{array}$ & $\begin{array}{c}\text { Welfare } \\
\text { Change } \\
\text { (Percent of GDP) }\end{array}$ & $\begin{array}{c}\text { Change in } \\
\text { Terms of Trade } \\
\text { (Percent) }\end{array}$ & $\begin{array}{l}\text { Change in } \\
\text { Welfare }\end{array}$ & $\begin{array}{c}\text { Welfare } \\
\text { Change } \\
\text { (Percent of GDP) }\end{array}$ & $\begin{array}{c}\text { Change in } \\
\text { Terms of Trade } \\
\text { (Percent) }\end{array}$ \\
\hline United States & 2115 & 0.03 & 0.1 & 3575 & 0.05 & 0.3 & 6182 & 0.08 & 0.4 \\
\hline Australia, Ncw Zealand, and Canada & 8512 & 0.78 & 1.6 & 1541 & 0.14 & 0.5 & 10276 & 0.94 & 2,2 \\
\hline Japan & 24949 & 0.59 & -0.7 & -2059 & -0.05 & -0.3 & 22333 & 0.52 & -1.1 \\
\hline European Union 15 & 20882 & 0.26 & -0.3 & 12519 & 0.16 & 0.0 & 31788 & 0.40 & -0.3 \\
\hline Korea & 3296 & 0.74 & -0.7 & -462 & -0.10 & -0.2 & 2948 & 0.66 & -0.9 \\
\hline Other OECD & 18877 & 1.46 & -0.8 & -1021 & -0.08 & -0.1 & 18150 & 1.41 & -0.9 \\
\hline China & 656 & 0.08 & 0.4 & -675 & -0.08 & 0.0 & -19 & 0.00 & 0.4 \\
\hline India & 62 & 0.02 & 0.4 & 66 & 0.02 & -0.1 & 143 & 0.04 & 0.7 \\
\hline $\begin{array}{l}\text { Hong Kong SAR, Taiwan POC, Singapore, } \\
\text { rest of ASEAN } 1 /\end{array}$ & 1791 & 0.16 & 0.2 & -406 & -0.04 & -0.1 & 1392 & 0.13 & 0.2 \\
\hline Rest of South Asia & 67 & 0.05 & 0.1 & -164 & -0.13 & -0.5 & -110 & -0.08 & -0.4 \\
\hline Brazil & 1542 & 0.20 & 0.9 & 735 & 0.09 & 0.4 & 2443 & 0.31 & 1.4 \\
\hline Argentina & 869 & 0.27 & 2.2 & 582 & 0.18 & 1.6 & 1552 & 0.48 & 4.0 \\
\hline Rest of Latin America & 2439 & 0.52 & 1.2 & -559 & -0.12 & -0.2 & 1995 & 0.42 & 1.1 \\
\hline North Africa and Middle East & 1171 & 0.16 & 0.2 & -2881 & -0.40 & -0.5 & -1873 & -0.26 & -0.3 \\
\hline Southern Africa Customs Union & 1424 & 0.99 & 2.6 & .57 & -0.04 & 0.0 & 1415 & 0.98 & 2.8 \\
\hline Rest of Sub-Saharan Africa & 1002 & 0.49 & 1.1 & -363 & -0.18 & -0.4 & 671 & 0.33 & 0.8 \\
\hline Former Soviet Union & 913 & 0.16 & 0.9 & .850 & -0.14 & -0.4 & 1 & 0.00 & 0.6 \\
\hline Rest of world & 559 & 0.20 & 0.7 & -161 & -0.06 & -0.1 & 395 & 0.14 & 0.6 \\
\hline World & 91124 & 0.31 & & 9359 & 0.03 & & 99681 & 0.34 & \\
\hline Developed countries & 78630 & & & 14092 & & & 91677 & & \\
\hline Perecent of Total & 86 & & & 151 & & & 92 & & \\
\hline Developing countries & 12494 & & & -4733 & & & 8005 & & \\
\hline Perccent of Total & 14 & & & -51 & & & 8 & & \\
\hline
\end{tabular}


gainers being the regions that have the most distorting policies in place, namely, the EU, Japan, the United States, and Korea. As a group, developed countries reap 92 percent of the total welfare gains from liberalization. In these countries, the efficiency gains from liberalization outweigh any adverse movements in their terms of trade. Gains also accrue to Argentina, Brazil, India, Latin America, and Sub-Saharan Africa, as these countries and regions enjoy greater access to developed countries' markets. Some of these countries (e.g. Brazil, Argentina, and India) also gain because they are net agricultural exporters and their terms of trade improve following liberalization. These results are broadly similar to those obtained by Anderson et al. (2001).

Note that when developed countries only liberalize, three regions (China, the Rest of South Asia, and the Middle East and North Africa) are worse off. This is because these regions are net-food importers, have high tariffs on food imports, and the latter two regions must pay higher prices for imported food. North Africa and the Middle East would be particularly hurt by developed country liberalization (it would lose about US $\$ 2$ billion), since it is a significant importer of food, particularly wheat and grains.

These results highlight some important differences between the partial- and generalequilibrium approaches. In the context of a partial-equilibrium model, one might expect that a larger number of developing countries would be worse off as a result of liberalization by developed countries, as world prices of food would rise and a large number of developing countries are net importers. However, there are at least three different channels at work in a general equilibrium setting that may lead to different results, compared to a partialequilibrium model. First, the general equilibrium model takes into account income effects that are ignored in the partial-equilibrium model. Liberalization by developed countries raises real income in these countries, which translates into an increase in demand for imports of all goods, some of which are exported by developing countries. (For example, liberalization would increase the demand for coffee, tea, and cocoa and these are important exports for sub-Saharan Africa). This increase in demand for developing country exports is obviously a welfare gain for developing countries, and this effect could offset the adverse terms-of-trade movement. Second, as agricultural support is removed in industrial countries, resourceslabor and capital-move out of the agricultural sector and into other sectors, such as manufacturing and services. Higher output in these sectors depress international prices of these products and this represents a welfare gain to developing countries who are netimporters of these products. Third, as emphasized in section two, net-importing countries could benefit from an increase in the world price if the country has distortions in place. As many developing countries tax their agricultural sectors, as argued by Oyejide (2000), agricultural output is below the optimum and imports exceed the optimum. An increase in the world price could raise welfare in this case, since output would rise and imports would decline, offsetting the effect of the production tax. So, the welfare effects of liberalization could differ depending on whether policies are evaluated in a partial or a general equilibrium setting.

One interesting result from the GTAP model is that sub-Saharan Africa gains relatively more (as a percent of GDP) when all industrial countries liberalize, compared to 
case where only all developing countries liberalize. This result occurs for at least two reasons. First, although tariffs on agricultural products are generally higher in developing countries, the total nominal amount of protection - tariffs and subsidies-on agricultural products is higher in industrial countries in the GTAP database because developing countries have virtually no subsidies in place. In fact, developing countries tend to tax their agricultural sectors, rather than subsidize them. In other words, the total wedge between domestic and world prices is higher in agriculture in developed countries. Second, a major difference between the two experiments is the effect of liberalization on the terms of trade for subSaharan Africa: when all industrial countries liberalize, the terms of trade for sub-Saharan Africa improve, while they deteriorate when all developing countries liberalize. When all developing countries remove support to their agricultural sectors, output contracts and resources move into other sectors, namely sub-Saharan Africa's export sectors, e.g. manufacturing. This increase in output and exports of manufacturing goods depresses the export prices of these goods, which is reinforced by the fact that developing countries tend to export similar products. Thus, developing country liberalization worsens sub-Saharan Africa's terms of trade. ${ }^{9}$

These results are broadly consistent with the findings from other studies such as Harrison, Rutherford, and Tarr (1995), who used a global general equilibrium model, benchmarked to 1992 data, to assess the impact of agricultural liberalization under the Uruguay Round. They found that: i) the global welfare gains would be about US $\$ 58$ billion (in 1992 prices); ii) industrial countries would reap 84 percent of these gains; and a few regions would lose, including the Middle East and North Africa. On the whole, developed countries themselves would gain the most from removal of their own agricultural distortions, with small benefits to other countries and losses to very few. Turned the other way, the cost of maintaining the pattern of agricultural protection is quite high, with most of the burden borne by developed countries themselves.

While complete agricultural trade liberalization by developed countries leads to welfare gains for the world, removing import tariffs generates a much larger welfare gain for the world than eliminating subsidies (both export and production), a result that is consistent with other modeling efforts, such as Cernat, Laird, and Turrini (2002). As shown in Table 15, elimination of all tariffs on agricultural imports in developed countries would generate a welfare gain for the world of over US $\$ 91$ billion, while subsidy removal would generate gains of only US $\$ 91 / 2$ billion. Furthermore, while no country or region loses as a result of removing tariffs on agricultural products in developed countries, a number of countries lose as a result of removing industrial country subsidies. ${ }^{10}$ This result is explained by the structure of trade: products that are subsidized (either through export or production subsidies) in developed countries are products that are, with a few exceptions, imported by the rest of the world, particularly developing countries. As a consequence, countries or regions that import

\footnotetext{
${ }^{9}$ Anderson (2002) finds a similar result from using the GTAP model to explore the implications of for sub-Saharan African of liberalization by Pacific-Rim countries.

${ }^{10}$ Cernat, Laird, and Turrini (2002) actually find that the world as a whole loses from removal of export subsidies, while Western Europe (EU) gains.
} 
the subsidized products lose when trade is liberalized, as they experience an adverse termsof-trade shock, i.e. the price of imports rises relative to the price of exports, as shown in table 15. Industrial country tariffs apply to a wider range of goods than subsidies--goods that developing countries export as well as import.

\section{Conclusions}

The complex array of agricultural support policies in developed countries clearly hurt the countries that impose them, as well as many poor, developing countries. Developed countries spend a significant portion of their output to support a sector that is small in relation to the size of their economies and employs relatively few workers. These facts demonstrate the political clout that the agricultural sector wields in developed countries.

Removal of agricultural support in developed countries would raise welfare in thcse countries by redirecting resources to more efficient uses and by reducing the price paid by consumers for agricultural products in most cases. The results presented in this paper show that agricultural support applied to beef and dairy products (e.g., milk) is particularly costly, as prices for these commodities in developed countries exceed world international prices by substantial margins. The partial equilibrium calculations show that agricultural support policies are particularly costly for Japan, Korea, Norway, and Switzerland, given the high levels of support in these countries.

The partial-equilibrium results also reveal some important information about the relative inefficiency of various types of agricultural support measures adopted in developed countries - market price support (import tariffs and export subsidies), output subsidies, and input subsidies. The results show that market price support, namely tariffs, have the largest distortionary effect among all types of support policies. While much of the popular rhetoric comdemns the use of subsidies by developed countries, the empirical evidence suggests that tariffs, rather than subsidies, have larger negative effects.

While removal of agricultural support benefits the countries that had such policies in place, liberalization may actually harm a number of countries-the net-food-importing countries - as a result of the increase in the international prices of food. The results in this paper show that the increase in the cost of imported food for these countries is generally small-less than 2 percent of affected imports - although some countries would be particularly hard hit by liberalization. These countries include the large net importers of grains (countries in the Middle East and North Africa) and dairy products. Some countries could actually experience an increase in net export revenue.

To provide a second perspective on the effects of liberalization, the paper presented the results from a using a global general equilibrium to evaluate the impact of agricultural trade liberalization. These simulations demonstrated a number of points that are important to keep in mind in the debate over the degree to which agricultural support in developed countries affects developing countries. First, removal of agricultural support in developed countries alone would result in a welfare gain to the world of about US $\$ 100$ billion, and over 90 percent of these gains would acrue to the countries that undertake liberalization. If only developing countries liberalized, the world would gain US\$24 billion, of which 80 percent 
would accrue to developing countries. These two simulations make the point that the benefits of liberalization are concentrated in the countries or groups of countries that undertake the liberalization. Hence, the costs of agricultural suppport are borne most heavily by the countries that have support policies in place. The simulations do show, however, that removal of agricultural support policies in developed countries generate benefits for one region of the world-sub-Sahran Africa-that are greater than the benefits that would arise if all developing countries were to liberalize. This result does not vitiate the general principle enunciated above; rather, it simply reflects the fact that agricultural support is, on average, higher in developed countries, compared with sub-Saharan Africa.

Second, the simulations show that while many developing countries benefit from removal of agricultural support in developed countries, some countries are harmed as a consequence of the fact that they are net importers of the liberalized product and thus, must pay more for food imports. Any policy proposal for liberalization should therefore include some mechanism that would address the potential balance of payments difficulties facing these countries.

Third, the popular press frequently cites the existence of developed country "subsidies" as being detrimental to the development of poor countries. The simulations presented here show the opposite: tariffs on imports of agricultural goods in developed countries are more detrimental to the interests of developing countries than subsidies. The basic reason for this is that developing countries, with a few exceptions (e.g., cotton), tend to be net importers of products subsidized by developed countries. In fact, the experiments show that developing countries as a group would be harmed by removal of subsidies alone, because of the terms of trade loss.

While both partial- and general-equilibrium models have been used to evaluate the effects of agricultural support, neither approach clearly dominates the other. As noted, each approach has advantages and disadvantages, so it is useful to use all approaches to shed as much light as possible on the welfare effects of removing agricultural support. The generalequilibrium model does takes into account a number of channels through which liberalization could affect welfare-channels that are not typically included in partial-equilibrium models. 


\section{References}

Anderson, James, 1998, "The Uruguay Round and Welfare in Some Distorted Agricultural Economies, Journal of Development Economics, Vol. 56 (August), pp. 393-410.

Anderson, Kym, 2002, Agricultural Trade Liberalization: Implications for Indian Ocean Rim Countries (Adelaide: Center for International Economic Studies).

- Betina Dimaranan, Joseph Francois, Tom Hertel, Bernard Hoekman, and Will Martin, 2001, "The Cost of Rich (and Poor) Country Protection to Developing Countries," Journal of African Economies, Vol. 10 (May), pp 227-57. , and Rod Tyers, 1993, "More on Welfare Gains to Developing Countries From Liberalizing World Food Trade," Journal of Agricultural Economics, Vol. 44, pp. 189-204.

Cernat, Lucian, Sam Laird, and Alessandro Turrini, 2002, "Back to Basics: Market Access Issues in the Doha Agenda," Geneva: (unpublished); United Nations Conference on Trade and Development (UNCTAD).

Corden, W. Max, 1957, "Tariffs, Subsidies, and the Terms of Trade," Economica, Vol. 24 (August), pp. 235-42.

Eiteljörge, Uwe, and Clinton Shiells, 1995, "The Uruguay Round and Net Food Importers," (Washington: IMF Working Paper 95/143).

Food and Agricultural Organization (FAO), database on agricultural trade by commodity, available on the web at www fao.org.

Francois, Joseph, Bradley McDonald, and Håkan Nordström, (1996), "The Uruguay Round: A Numerically Based Qualitative Assessment," in The Uruguay Round and the Developing Countries, ed. by Will Martin and L. Alan Winters (Cambridge: Cambridge University Press).

Gardiner, Bruce, Vernon Roningen, and Karen Liu, 1989, "Elasticities in the Trade Liberalization Database," Staff Report No. AGES 89-20 (Washington: Economic Research Service, U.S. Department of Agriculture).

Harrison, Glenn, Tom Rutherford, and David Tarr, (1997), "Quantifying the Uruguay Round," in ed. by Will Martin and L. Alan Winters The Uruguay Round and Developing Countries, (Cambridge: Cambridge University Press).

Hertel, Thomas, ed., 1997, Global Trade Analysis: Modeling and Applications (Cambridge: Cambridge University Press). 
Hoekman, Bernard, Francis Ng, and Olarreaga Marcelo, 2002, "Reducing Agricultural Tariffs Versus Domestic Support: What's More Important For Developing Countries?" Washington: World Bank Working Paper 2918, (October).

International Monetary Fund, 2002, How Do Industrial Country Agricultural Policies Affect Developing Countries?", World Economic Outlook, (September), pp. 81-91.

Johnson, Harry, 1960, "The Cost of Protection and the Scientific Tariff," Journal of Political Economy, Vol. 68, No. 4, (August).

Martin, Will, 1996, "Measuring Welfare Changes," in Applied Methods for Trade Policy Analysis, eds. J. Francois and K. Reinert, Cambridge: Cambridge University Press.

Metzler, Lloyd, 1949, "International Demand and Domestic Prices," Journal of Political Economy, Vol. 57, pp. 345-351 (August).

Organization For Economic Cooperation and Development (OECD) 2001, Market Effects of Crop Support Measures, Paris.

$\longrightarrow$, 2002, Agricultural Policies in OECD Countries-Monitoring and Evaluation, Paris.

Oyejide, T. Ademola, 2000, "Agriculture in the Millennium Round of Multilateral Trade Negotiations: African Interests and Options," in Agricultural Trade Liberalization in a New Trade Round, ed. by Merlinda Ingco and L. Alan Winters, Washington, D.C.: The World Bank, pp.11-23.

Vanzetti, David, and Brett Graham, 2002, "Simulating Agricultural Policy Reform With ATPSM," Geneva: United Nations Conference on Trade and Development (UNCTAD), Paper presented at the Fourth European Trade Study Group Conference, (September).

World Trade Organization (WTO), 2002, WTO List of Net-Food Importing Developing Countries For the Purposes of the Marrakesh Ministerial Decision On Measures Concerning the Possible Negative Effects of the Reform Programme on LeastDeveloped and Net Food-Importing Countries ("The Decision"), Committee on Agriculture, G/AG/5/Rev. 5, (March). 